\title{
Investigation of different analysis methods for chloride profiles within a real structure in a marine
} environment

Ines.Othmen ${ }^{\mathrm{a}, 1}$, Stéphanie Bonnet ${ }^{\mathrm{b}}$, Franck Schoefs ${ }^{\mathrm{a}}$

${ }^{a}$ UBL, Université de Nantes, GeM, CNRS UMR 6183, 2 rue de la Houssinière (BP 92208), 44322 Nantes Cedex 03, France

' UBL, Université de Nantes, GeM, CNRS UMR 6183, 58 rue Michel Ange (BP420), 44606 Saint Nazaire Cedex, France

${ }^{1}$ Corresponding author.

E-mail: ines.othmen@gmail.com

Tel : +33 (0)253487302

\section{Abstract}

Corrosion is a major problem for durability of reinforced concrete structures in a marine environment. To establish the best accurate planning for maintenance operations, assessing chloride ingress within concrete is essential. The present paper reports a study conducted to investigate a large amount of field chloride data collected from a 28-years old beam in a splash zone. The chloride profiles are examined based on Fick's second law to estimate the surface content $C_{s}$ and the diffusion coefficient $D$. Firstly, three different cases considering the location of the maximum chloride content are tested: a reference case (individual analysis), a 15-mm discarded case and a 20-mm discarded case (generic treatments). The results highlight the importance of the individual analysis. $C_{s}$ and $D$, indeed, appear to be significantly affected by the generic treatment, the relative error being around $50 \%$ for $C_{s}$ and $100 \%$ for $D$. A focus is therefore placed on the individual analysis. The coefficients of variation are $44 \%$ and $61 \%$ for $C_{s}$ and $D$, respectively. For the statistical distribution, both parameters show a clear dependence. They also follow a lognormal law with a mean value ranging between 0.0057 and $0.0085 \mathrm{~kg}_{\mathrm{Cl}} / \mathrm{kg}_{\text {concrete }}$ for $C_{s}$ and equal to $1.3 \times 10^{-12} \mathrm{~m}^{2} / \mathrm{s}$ for $D$.

Key words: reinforced concrete, splash zone, chloride profiles, individual treatment, generic treatment, statistical analysis 
1. Introduction

Chloride penetration into concrete can cause irreversible damage within reinforced concrete structures, predominantly corrosion damage, when chloride content at the surface of reinforcement bars reaches a certain threshold level. Steel corrosion initiation is then a key indicator for the estimation of service life. The risk of corrosion damage is higher in a marine environment because of significant humidity and chloride contents in both seawater and air. Consequently, the corrosion of engineering structures is more severe in coastal areas than inland locations (Guo et al., 2015). Chloride profile analysis, is therefore, an important tool for service life predictions of structures and inspection/maintenance/repair action scheduling (Bastidas-Arteaga et al., 2011; de Rincón et al., 2004). Recent studies have highlighted the spatial variability of chloride-induced reinforced concrete corrosion with an impact on infrastructure network maintenance optimization (O'Connor and Kenshel, 2013). In the following, the focus is on total chloride content because, firstly, measurement methodology is not subject to debate (Bonnet et al., 2017) and, secondly, because it is the key parameter for already available maintenance optimisation methods.

Chloride profile analysis is therefore essential. Profiles are better assessed when different factors like concrete properties (Tadayon et al., 2016) and period of exposure (Mangat and Molloy, 1994, Tamimi et al., 2008) are taken into account. Exposure (above sea level: atmospheric and splashing zones, and under sea level: tidal and immersed zones) and environmental conditions (temperature, relative humidity, wind, orientation...) are also important factors in affecting the durability of concrete and in shortening the life span of structures. Many studies have shown that tidal and splash zones drive the most severe conditions as regards chloride ingress and steel corrosion of concrete in comparison with atmosphere and immersed zones (Valipour et al., 2013). Li and Shao (2014) conclude that immersed zones allow for a service life 1.6 to 3.9 times longer than splash zones, whatever the binding isotherm considered. Furthermore, in marine exposure conditions, chloride ions can penetrate into concrete through multiple mechanisms including diffusion, adsorption, permeation and surface deposit of airborne salts (Hilsdorf and Kropp, 2004). Although chloride ingress within concrete involves many mechanisms, it is widely accepted that diffusion is the primary mechanism (Pang and Li, 2016). Hence, chloride ingress can be modelled by the empirical Fick's diffusion model. Besides, The Fick's model is used by engineers and researchers to deal with in situ data (see references on table 1) and recommended by codes like Fédération International du Béton (2006) for its simplicity and its capacity of being adapted to different exposure cases. 
Indeed, a comparison of an oversimplified model to an improved model shows that both yields to similar results (Nguyen et al., 2017) and fairly well predict the chloride ingress in a Portland cement (up to 100 years) (Luping and Gulikers, 2007). Moreover, a long-term monitoring on real concrete structures exposed to environmental conditions makes the empirical Fick's model adapted for durability design (Li et al., 2015).

Then, many studies have been devoted to the measurement of chloride ingress within real structures like decks, piles, offshore platform or concrete specimens, in a marine environment with different exposure conditions (Table 1). The chloride profiles obtained (often) have the shape of a bell with a chloride content, which increases from the concrete surface to a certain depth where a maximum content, noted $C_{\text {peak }}$ in Table 1 , is reached and then decreases as depth increases. This is accounted for by (Andrade et al., 1997) as "concrete surface skin effect". In the studies reported in Table 1, the approach commonly used to estimate both surface content $C_{s}$ and diffusion coefficient $D$ come from the fitting of the Fick's second law to in-situ values of experimental chloride profiles. This regression beginning at $C_{\text {peak }}$ provides $C_{s}$ and $D$ simultaneously.

It should be noted that the value of $C_{\text {peak }}$ varies from $0.0014 \mathrm{~kg}_{\mathrm{Cl}-} \mathrm{kg}_{\text {concrete }}$ (Pang and Li, 2016) to 0.013 $\mathrm{kg}_{\mathrm{Cl} /} \mathrm{kg}_{\text {concrete }}$ (Chalee et al., 2009). $C_{\text {peak }}$ can also start at $0 \mathrm{~mm}$ (Chalee et al., 2009; de Rincón et al., 2004), around $10 \mathrm{~mm}$ (Medeiros-Junior et al., 2015; Pang and Li, 2016; Thomas and Matthews, 2004), and at $20 \mathrm{~mm}$ or $30 \mathrm{~mm}$ (de Rincón et al., 2004). The depth may vary in relation to concrete quality, exposure conditions and structure orientation. Some values of $D$ obtained vary between $0.27 \times 10^{-12} \mathrm{~m}^{2} / \mathrm{s}$ (da Costa et al., 2013) and $5.13 \times 10^{-12} \mathrm{~m}^{2} / \mathrm{s}$ (Medeiros-Junior et al., 2015).

Among key parameters and phenomena (quality of concrete, exposure conditions and orientation) affecting structure service life, exposure conditions are the focus of this research. The present paper, indeed, reports the experimental investigation carried out on a 28-years old beam made from the same concrete composition and on which all the chloride profiles are measured on the same horizontal line (coring is performed on the same line along the beam). Moreover, the studied beam is located in a splash zone influenced by two local microclimates (both beam exposures are detailed in $§ 2.1$ ). The present study also provides a significant number of chloride profiles in accordance with (Medeiros-Junior et al., 2015), who underline the significance of the number of samples as a direct benefit to achieve precise statements. Furthermore, De Vera G. et al. (2015) highlighted that to assign reliable values for $C_{S}$ it is only possible on the basis of experimental chloride profiles obtained with the similar concrete composition and in similar locations. As for $D$, the sensitivity analysis realised by Li et al. 

(2009) shows that the achieved reliability of design is rather sensitive to the mean of $D$ values as well as the cover thickness. It is thus necessary to evaluate $D$ accurately.

These data form a substantial high value data base to improve the scientific documented knowledge library for concrete subject to XS3 class environmental exposure according to the NF EN 206-1 standard. The objective of this research is to address the problem of the determination of $C_{s}$ that usually results from the chloride content reduction at the concrete surface (Song et al., 2008). So, the variation of the position where $C_{p e a k}$ is measured appears to constitute a possible alternative route for study.

Thus, this paper provides an important data base of chloride measurements done on the same beam with reduced settings like concrete composition, location, marine environment and tidal height that were all the same for 30 core samples. Indeed, approximately 600 chloride measurements were carried out to highlight the observations and comments done hereafter. On a comparable data, it is possible, on the one hand, to underline the variability of the raw data of chloride profiles and, on the other hand, the variability of $C_{s}$ and $D$ along the beam once the raw data was processed by Fick's second law solution. This work, as far as we know, has never been done on so many data.

Since very numerous comparable data are available it led us to review the generic treatment used by some authors to deal with chloride profiles to determine $C_{s}$ and $D$ (Chalee et al., 2009; da Costa et al., 2013; Pang and $\mathrm{Li}, 2016)$.This treatment was compared to the individual treatment called reference case in this paper which is more time consuming than the previous treatment.

Accordingly, the paper is structured as follows:

- $\quad$ Experimental investigation of the studied structure.

- $\quad$ Experimental chloride profile fitting methodology based on three sets of analyses depending on the chloride maximum content position and using Fick's second law to assess $C_{s}$ and $D$.

- $\quad C_{s}$ and $D$ results presentation for the three sets of analyses. The focus is made on the reference case to derive the statistical distribution and the covariance.

Table 1: Peak values of total ${ }^{* *}$ chloride content and diffusion coefficient of concrete structures and specimens exposed to a marine environment

\begin{tabular}{|c|c|c|c|c|c|c|c|c|}
\hline Reference & Structure & $\begin{array}{l}\text { Exposure } \\
\text { conditions }\end{array}$ & $\begin{array}{l}\text { Construction } \\
\text { period }\end{array}$ & $\begin{array}{l}\text { Investigation } \\
\text { period (year) }\end{array}$ & $\begin{array}{l}\text { Number } \\
\text { of } \\
\text { samples }\end{array}$ & $\begin{array}{l}\text { Peak } \\
\text { position } \\
(\mathrm{mm})\end{array}$ & $\begin{array}{l}\mathrm{C}_{\text {peak }}{ }^{*} \\
\mathrm{~kg} / \mathrm{kg}\end{array}$ & $\begin{array}{l}\mathrm{D}^{*} \\
10^{-12} \\
\mathrm{~m}^{2} / \mathrm{s}\end{array}$ \\
\hline \multirow{2}{*}{$\begin{array}{l}\text { (de Rincón et } \\
\text { al., 2004) }\end{array}$} & Bridge & \multirow{2}{*}{$\begin{array}{l}\text { Above the } \\
\text { sea level }\end{array}$} & $1962-1963$ & 33 & \multirow{2}{*}{ - } & \multirow{2}{*}{$\begin{array}{c}\text { Around } \\
20-30\end{array}$} & 0.0028 & \multirow[t]{2}{*}{-} \\
\hline & pier & & 1938 & 64 & & & 0.0025 & \\
\hline
\end{tabular}




\begin{tabular}{|c|c|c|c|c|c|c|c|c|}
\hline & bridge & & 1986 & 11 & & 0 & 0.0018 & \\
\hline $\begin{array}{l}\text { (da Costa et al., } \\
\text { 2013). }\end{array}$ & $\begin{array}{l}\text { Offshore } \\
\text { oil } \\
\text { platform }\end{array}$ & $\begin{array}{l}\text { Wetting } \\
\text { drying cycles }\end{array}$ & & 25 & 35 & $\begin{array}{l}\text { Around } \\
10-20\end{array}$ & $\begin{array}{l}0.0029 \\
: \\
0.0051 \\
\end{array}$ & $\begin{array}{l}0.27: \\
1.6\end{array}$ \\
\hline $\begin{array}{l}\text { (Chalee et al., } \\
\text { 2009) }\end{array}$ & $\begin{array}{l}\text { Cube } \\
\text { specimens } \\
\text { (in sea } \\
\text { water) } \\
\end{array}$ & $\begin{array}{l}\text { Two wet dry } \\
\text { cycles of sea } \\
\text { water daily }\end{array}$ & - & 5 & - & $0 \mathrm{~mm}$ & 0.013 & 1.65 \\
\hline $\begin{array}{l}\text { (Pang and Li, } \\
\text { 2016) }\end{array}$ & $\begin{array}{l}\text { Pile wharf } \\
\text { structure }\end{array}$ & splash zone & $\begin{array}{l}\text { between } \\
1971 \\
2008\end{array}$ and & 36 & $\begin{array}{c}\text { 8/pile } \\
14 \text { piles } \\
\text { tested }\end{array}$ & $\begin{array}{l}\text { Between } \\
0 \text { and } 10\end{array}$ & 0.0046 & 0.35 \\
\hline $\begin{array}{l}\text { (Medeiros- } \\
\text { Junior et al., } \\
2015 \text { ) }\end{array}$ & $\begin{array}{l}\text { Offshore } \\
\text { platform }\end{array}$ & splash zone & 1976 & 29 & $\begin{array}{c}3 \text { layers/ } \\
\text { point of } \\
\text { investi- } \\
\text { gation }\end{array}$ & 10 & 0.007 & 5.13 \\
\hline $\begin{array}{l}\text { (Thomas and } \\
\text { Matthews, } \\
\text { 2004) }\end{array}$ & $\begin{array}{l}\text { Cube } \\
\text { specimens } \\
\text { (in sea } \\
\text { water) }\end{array}$ & Tidal zone & - & 1,2 and 10 & - & $\begin{array}{l}\text { around } \\
7.5-10\end{array}$ & $\begin{array}{l}0.0038 \\
: 0.006\end{array}$ & - \\
\hline $\begin{array}{l}\text { (Pritzl et al., } \\
2015 \text { ) }\end{array}$ & $\begin{array}{l}\text { Deck } \\
\text { bridge }\end{array}$ & $\begin{array}{l}\text { deicing salt } \\
\text { environment }\end{array}$ & $\begin{array}{l}\text { Between } \\
1992 \\
1995\end{array}$ and & 16 & $\begin{array}{c}4 \\
\text { locations }\end{array}$ & 10 & 0.0059 & 2 \\
\hline $\begin{array}{l}\text { (Tadayon et al., } \\
\text { 2016) }\end{array}$ & $\begin{array}{l}\text { Cube } \\
\text { specimens } \\
\text { (in sea } \\
\text { water) }\end{array}$ & Tidal zone & - & $\begin{array}{c}4.17 \\
(=50 \text { months })\end{array}$ & - & 2.5 & $\begin{array}{l}0.006: \\
0.0091\end{array}$ & $2: 4.2$ \\
\hline $\begin{array}{l}\text { (Cramer et al., } \\
\text { 2002) }\end{array}$ & bridge & $\begin{array}{l}\text { Marine } \\
\text { breeze }\end{array}$ & - & 40 to 60 & - & - & $\begin{array}{l}0.0073 \\
: \\
0.003 \\
\end{array}$ & $\begin{array}{l}0.41: \\
1.71\end{array}$ \\
\hline (Kenshel, 2009) & pier & $\begin{array}{l}\text { Atmospheric } \\
\text { zone }\end{array}$ & 1980 & 27 & 45 & $\begin{array}{l}\text { Between } \\
10 \text { and } 25 \\
\mathrm{~mm}\end{array}$ & $\begin{array}{l}0.0004 \\
: \\
0.0013 \\
\end{array}$ & $\begin{array}{l}0.098 \\
: \\
0.72 \\
\end{array}$ \\
\hline
\end{tabular}

*Peak position is the position within the sample where the maximum chloride content $\left(C_{\text {peak }}\right)$ is measured. When information are missing to convert $C$ and D into $\mathrm{kg} / \mathrm{kg}$ and $\mathrm{m}^{2} / \mathrm{s}$, respectively, we considered Cement concentration $=350 \mathrm{~kg} / \mathrm{m}^{3}$ and concrete bulk density $=2500 \mathrm{~kg} / \mathrm{m}^{3}$

** except for Medeiros-Junior et al., 2015 where only free chloride content is measured

2. Experimental investigation of the studied structure

Harbour infrastructures, especially energy-related ones, are important components of the transportation system in

114 coastal areas. We, therefore, focus on the coal terminal of the test area. The coal terminal is located within the

115 industrial and port activity area, which includes many specialised facilities near the city of Saint-Nazaire

116 (France). The coal terminal, which is one of the largest thermal power stations in Europe, is used for the import

117 and then the transportation of coal by inland waterways to support French power supply.

118 The coal terminal (Fig. 2a), built between 1981 and 1983, consists of five bridge piers (54.5m in length *9.8 m

119 in width each) giving access to an unloading platform (246.4 $\mathrm{m}$ in length* $20.7 \mathrm{~m}$ in width). 
For accessibility reasons, the study is conducted on beam $\mathrm{J}$ of Pier 5 (Fig. 1b). The beam is $9.35 \mathrm{~m}$ long and $0.40 \mathrm{~m}$ wide. The upstream side, exposed to weather variations, is called "exposed side" (noted ES) whereas the protected downstream face being situated in a confined environment is called "sheltered side" (noted SS) (Fig. 1c and Fig. 1d). Beam J is located in the estuary area of the Loire River less than $7 \mathrm{~km}$ from the Atlantic Ocean.

The beam is situated $5.8 \mathrm{~m}$ above sea level, in a splash zone where the bottom of the beam may be in contact with seawater when tidal coefficients are high (roughly 2 days/month). The climatic data, including temperature (T), relative humidity $(\mathrm{RH})$ and wind speed, cumulative rainfall and the atmospheric pressure $(\mathrm{P})$, have been recorded by the French Government weather station ${ }^{1}$ near the Saint-Nazaire harbour (Table 2). Temperature mean maximal and minimal values are $16.9^{\circ} \mathrm{C}$ and $8.7^{\circ} \mathrm{C}$, respectively, with high relative humidity (>80\%).

Table 2: Climatic data of the beam surrounding environment

\begin{tabular}{|c|c|c|c|c|c|c|c|c|c|}
\hline & & $\begin{array}{c}\text { Mean } \\
\max \mathrm{T} \\
{\left[{ }^{\circ} \mathrm{C}\right]} \\
\end{array}$ & $\begin{array}{c}\text { Mean } \\
\min \mathrm{T} \\
{\left[{ }^{\circ} \mathrm{C}\right]} \\
\end{array}$ & $\begin{array}{c}\text { Mean } \\
\text { RH } \\
{[\%]} \\
\end{array}$ & $\begin{array}{c}\text { Maximal } \\
\text { Wind speed } \\
{[\mathrm{km} / \mathrm{h}]}\end{array}$ & $\begin{array}{c}\text { Cumulative } \\
\text { Rainfall } \\
\text { [mm] }\end{array}$ & $\begin{array}{c}\text { Max rainfall } \\
\text { per } 24 \mathrm{~h} \\
{[\mathrm{~mm}]}\end{array}$ & $\begin{array}{l}\text { Max P } \\
{[\mathrm{hPa}]}\end{array}$ & $\begin{array}{l}\text { Min P } \\
{[\mathrm{hPa}]}\end{array}$ \\
\hline $\begin{array}{l}\text { Mean } \\
\text { (between } \\
\text { and 2011) }\end{array}$ & $\begin{array}{l}\text { value } \\
1981\end{array}$ & 16.9 & 8.7 & $>80 \%$ & 133.3 & 788.6 & 61.8 & 961.6 & 1088 \\
\hline
\end{tabular}
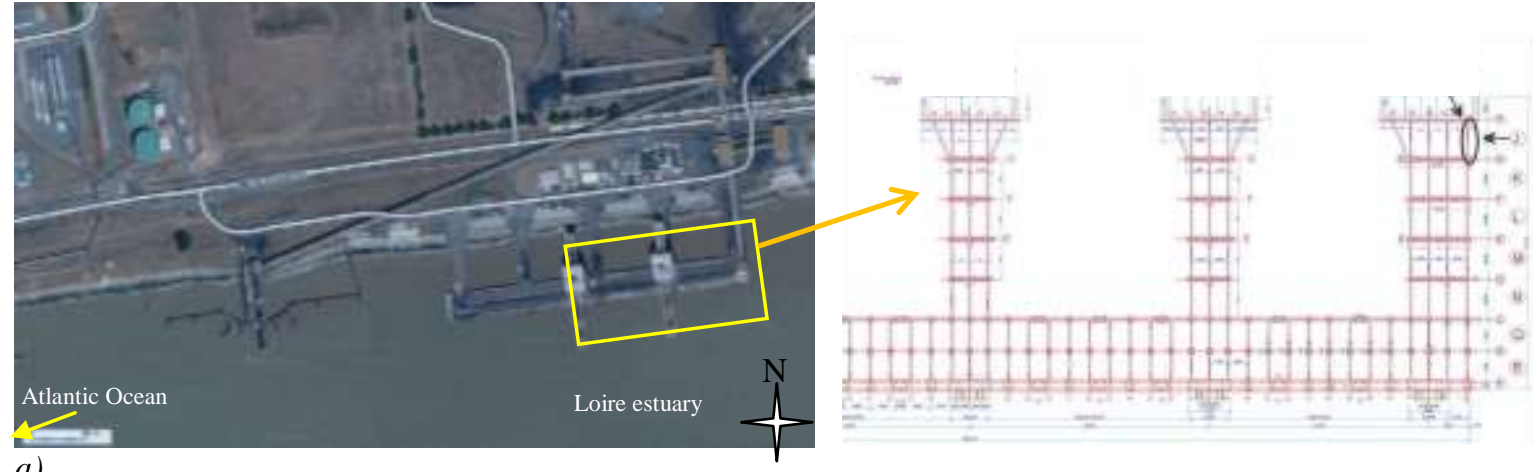

a)

b)
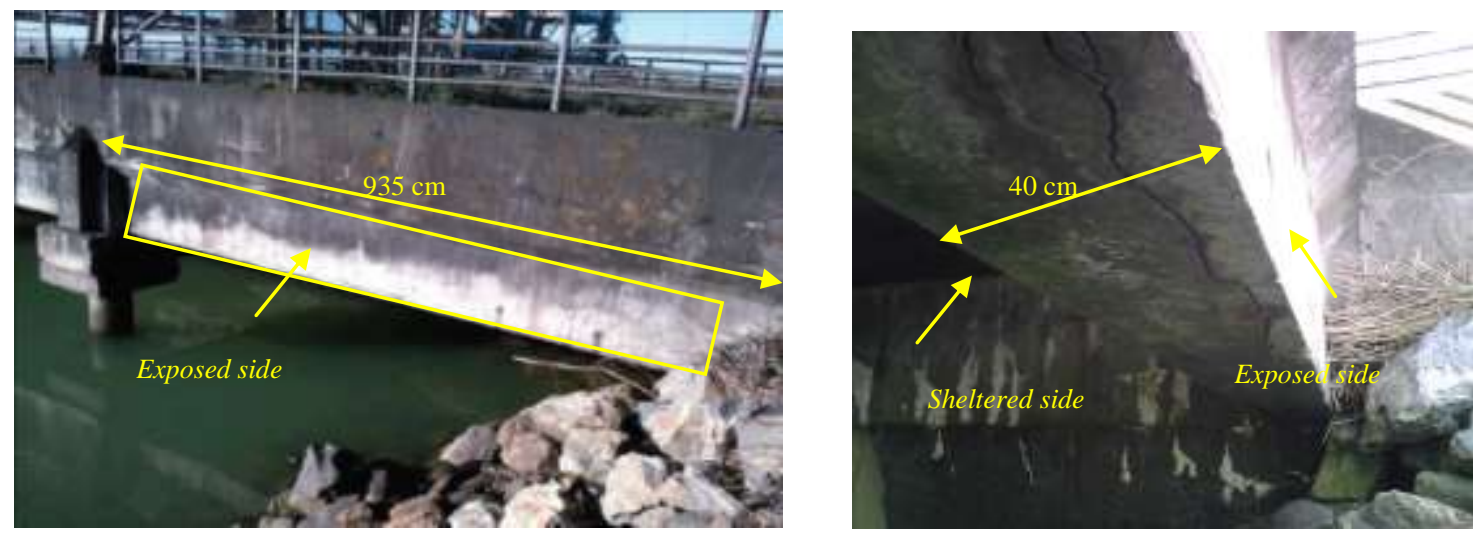

c)

d)

\footnotetext{
${ }^{1}$ http://www.infoclimat.fr/stations-meteo/climato-moyennes-records.
} 
Fig. 1: Coal terminal a) aerial view b) sketch of bridges 3,4 and 5 c) Picture of beam J d) Exposed and sheltered sides of beam $\mathbf{J}$

\subsection{Concrete composition}

When studying the existing documentation from the coal terminal, we find some data available about the concrete. It is a Portland cement where clinkers make up more than $90 \%$ of the cement and secondary constituents shall not exceed 5\%. The cement has also a strength class of $45 \mathrm{MPa}$. The aggregates used are sand $0 / 6$ and gravel $5 / 10$ and $10 / 25$. The cement content of $350 \mathrm{~kg} / \mathrm{m}^{3}$ is specified but not aggregate and water contents.

Concrete open water porosity and compressive strength are both measured on the central parts of the extracted cores that were sawn and rectified to obtain a flat surface (slide Number 3 in Fig. 2c).

Concrete cylinders were oven-dried at $60{ }^{\circ} \mathrm{C}$ until reaching constant weight. Then they were cooled for $48 \mathrm{~h}$ in a desiccator at $20^{\circ} \mathrm{C}$ before being water saturated to determine their open water porosity (Ben Fraj et al., 2012).

The porosity is obtained from five samples with a mean value of $13.7 \%$ (min value $=11.3 \%$ and max value $=15.9 \%$ ). The compressive strength is obtained from four $5-\mathrm{cm}$ diameter and $10-\mathrm{cm}$ long samples. The loading speed was of $5 \mathrm{kN} / \mathrm{s}$. The mean value is $43.5 \mathrm{MPa}$ ( $\min$ value $=38.5 \mathrm{MPa}$ and $\max$ value $=48.9 \mathrm{MPa})$.

\subsection{Experimental investigation for chloride content}

The extraction of the cylindrical cores took place in 2011 after 28 years of exposure and carried out along a line situated $30 \mathrm{~cm}$ above the bottom of the beam. Thirty samples have been collected every $30 \mathrm{~cm}$ (red dots in Fig. 2a) and numbered from 1 to 30 from the Loire estuary side to the embankment side of the beam.

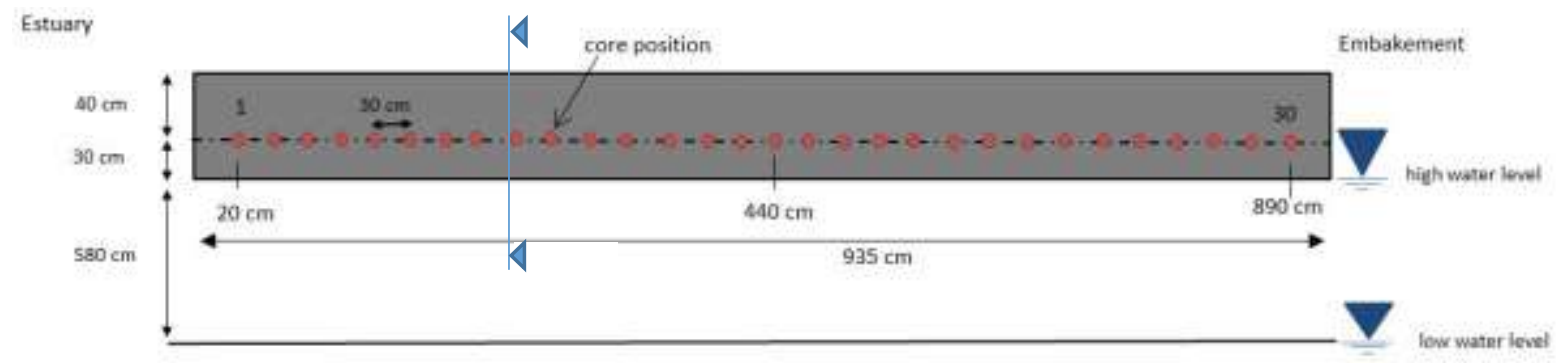

a) 


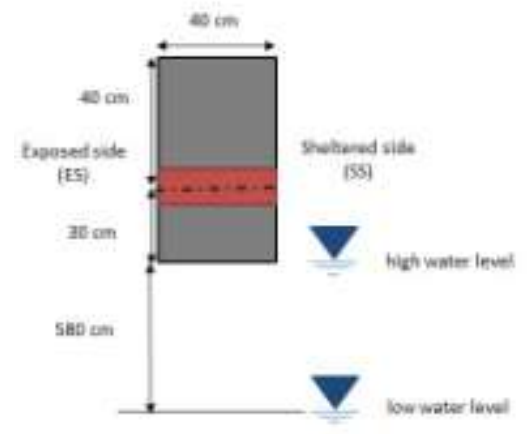

b)

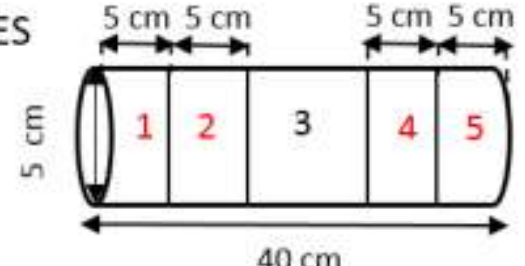

c)

Fig. 2: Investigation line a) front view with cores positions b) cross section A-A and c) sample diagram

The thirty specimens are cylinders $5 \mathrm{~cm}$ in diameter and $40 \mathrm{~cm}$ in length. Each core is cut into five slices: slices 1 and 2 correspond to the exposed side (ES) and slices 4 and 5 to the sheltered side (SS) (Fig. 2c). All are used to determine the chloride profiles. Slice $\mathrm{n}^{\circ} 3$ is used for other investigations like porosity and compressive strength (§2.2) and for the determination of the initial chloride content $(\S 3.2)$.

The procedure recommended by the RILEM Technical Committee 178-TMC ("Recommendation for analysis of total chloride in concrete.," 2006) is followed to obtain the chloride profiles. Slices are grounded first into 5-mm thick layers up to a depth of $5 \mathrm{~cm}$ (slices 1 and 5 in Fig. 2c) and then into 10-mm thick layers for the remaining 5 $\mathrm{cm}$ (slices 2 and 4 in Fig. 2c). This method makes it possible to monitor the progression of the fitting and to assess the peak position on the profile with good accuracy $(+/-2.5 \mathrm{~mm})$, the other parts of the core (\# 2 and \#4) having less impact on the fitting accuracy. For the recovery of powder, grounding is made perpendicularly to the top faces of the cylinders using a grinding instrument as recommended by Vennesland (Vennesland et al., 2012). The powder is collected and stored in sealed plastic bags. The procedure described below is used to determine the total chloride content from concrete powder (Chaussadent and Arliguie, 1999; Vennesland et al., 2012). In order to extract the chloride from the concrete powder samples, $100 \mathrm{ml}$ of nitric acid is added to $5 \mathrm{~g}$ of grounded concrete powder. The mixture is heated and stirred for $30 \mathrm{~min}$. The solution obtained is then filtered into a $250-\mathrm{cm}^{3}$ volumetric flash. The chloride content of the filtered solutions is finally determined by potentiometric titration using an automatic titrator with $0.05-\mathrm{M}$ silver nitrate $\left(\mathrm{AgNO}_{3}\right)$ as titrant.

\section{Fitting method}

\subsection{Chloride profiles}

The chloride content is plotted as a function of the distance (in $\mathrm{mm}$ ) from the top surface for both sides (SS and ES) to illustrate chloride profiles. Samples are numbered from 1 to 30 as shown in Fig. 2 a. 37 workable profiles 
are thus obtained, which are distributed as follows: 21 profiles from the sheltered side (SS) and 16 profiles from the exposed side (ES). The profiles are summarized in Table 3 (cross mark means availability).

Missing profiles 9, 11, 12 and 26 correspond to the cores damaged during sampling. Other profiles have also been eliminated. Indeed, when plotting chloride concentrations as a function of depth, some profiles present a linear trend suggesting the presence of cracks that may trap a significant amount of chloride (Erreur ! Source du renvoi introuvable.-curves with empty markers).

Wang et al. (2016) have examined the effects of different crack parameters on the chloride diffusion into concrete and have demonstrated that it highly depends on the crack density (represents the amount of cracks), in addition to crack width and crack tortuosity.

An outlier reveals a very high chloride content in the chloride profile, which should then be discarded. The discarded profiles here are 3,15 17, 20 and 29 on the sheltered side and 3, 6, 7, 8, 9, 15, 17, 20, 22 and 29 on the exposed side. 37 profiles are finally processed. The mean global profile, represented as the mean chloride content for both sides (mean of the 37 profiles), is given in Fig. 3 (blue solid line).

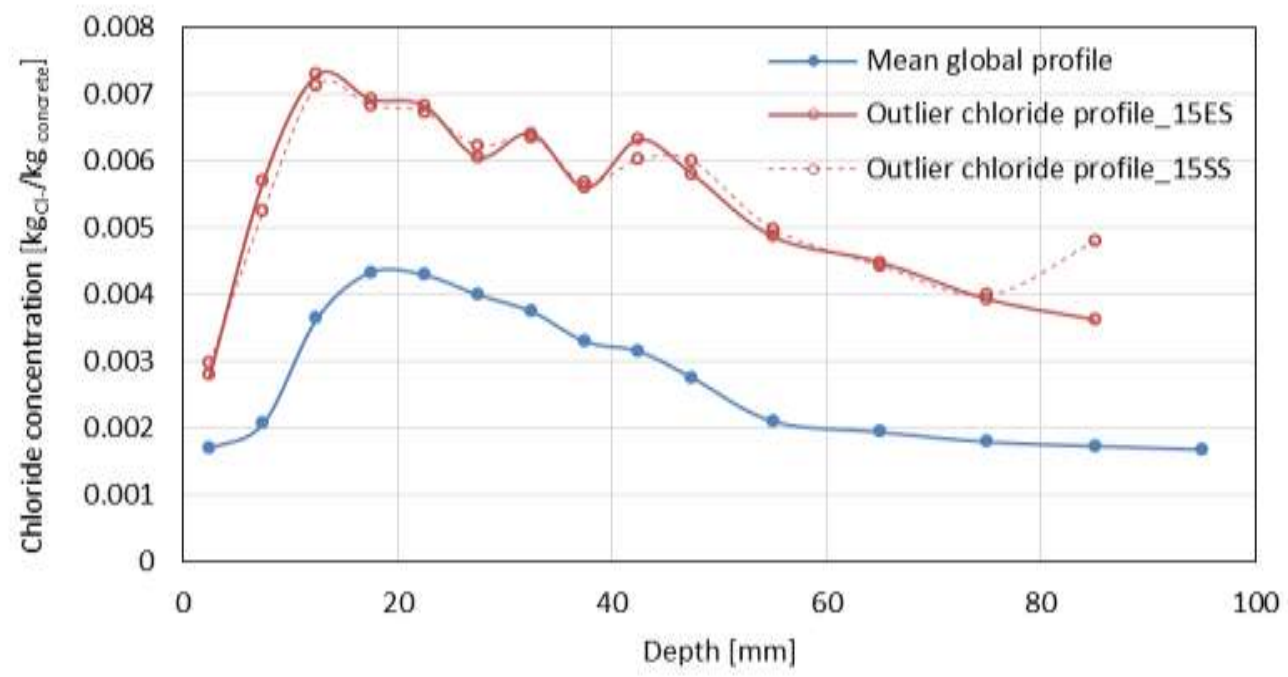

Fig. 3: Example of profiles with outliers (high values of concentration) with respect to the global mean profile

Table 3: Summary of the profiles obtained

\begin{tabular}{|c|c|c|c|c|c|c|c|c|c|c|c|}
\hline Sample & Position $(\mathrm{cm})$ & SS & ES & Sample & Position $(\mathrm{cm})$ & SS & ES & Sample & Position $(\mathrm{cm})$ & SS & ES \\
\hline 1 & 20 & 凶 & 凶 & 11 & 320 & $\square$ & $\square$ & 21 & 620 & 凶 & 区 \\
\hline 2 & 50 & 区 & 凶 & 12 & 350 & $\square$ & $\square$ & 22 & 650 & 区 & $\square$ \\
\hline 3 & 80 & $\square$ & $\square$ & 13 & 380 & 区 & 凶 & 23 & 680 & 凶 & $\mathrm{X}$ \\
\hline 4 & 110 & 凶 & 凶 & 14 & 410 & 区 & 凶 & 24 & 710 & 凶 & $\mathrm{X}$ \\
\hline 5 & 140 & 凶 & 区 & 15 & 440 & $\square$ & $\square$ & 25 & 740 & 区 & X \\
\hline
\end{tabular}




\begin{tabular}{|c|c|c|c|c|c|c|c|c|c|c|c|}
\hline 6 & 170 & 凶 & $\square$ & 16 & 470 & 凶 & 凶 & 26 & 770 & $\square$ & $\square$ \\
\hline 7 & 200 & 凶 & $\square$ & 17 & 500 & $\square$ & $\square$ & 27 & 800 & 凶 & 凶 \\
\hline 8 & 230 & 凶 & $\square$ & 18 & 530 & 凶 & 凶 & 28 & 830 & 凶 & 凶 \\
\hline 9 & 260 & $\square$ & $\square$ & 19 & 560 & 凶 & $\square$ & 29 & 860 & $\square$ & $\square$ \\
\hline 10 & 290 & $凶$ & 凶 & 20 & 590 & $\square$ & $\square$ & 30 & 890 & 凶 & 凶 \\
\hline
\end{tabular}

For the sake of clarity, only mean chloride ingress profiles and error bars corresponding to standard deviation are presented in Fig. 4 for both exposures. The mean value is calculated for both sides from the retained experimental profiles (21 and 16 profiles for SS and ES, respectively). It ought to be pointed out that the number of profiles is very high and composes a substantial high value data base that can be used to estimate low order statistics (mean and standard deviation) with a low statistical uncertainty. It should also be reminded here that all the chloride profiles studied come from the same structure, with the same concrete material and the same environmental conditions (constant height above sea level, orientation, exposure, etc.). However, despite this, all the points of the profiles display a high standard deviation.

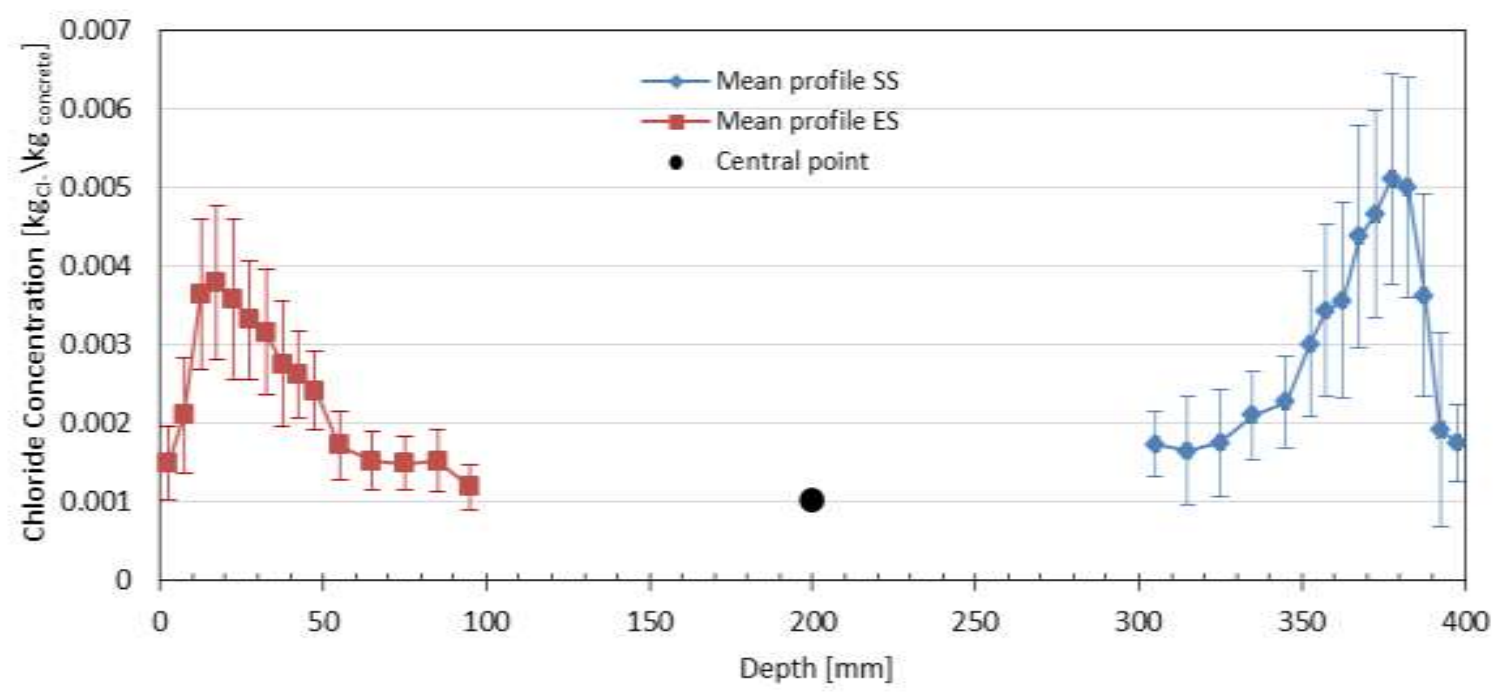

Fig. 4: Mean chloride profiles for both exposures (SS and ES) and for the central point (used as initial chloride content)

The chloride profiles from both sides of the beam (SS and ES) reveal identical behaviour: first, a low chloride content at the concrete surface, which increases to a peak value (around $20 \mathrm{~mm}$ for the mean profile) and then decreases to the central point (estimated from eight samples and corresponding to slice $n^{\circ} 3$ on Fig. $2 c$ ). Then the chloride profiles reveal the well-known bell shape as it appears in many researches (Song et al., 2008; Win et al., 2004). It should also be noted that the standard deviation values are higher and more variable on the sheltered side (Fig. 5a) and that they remain lower than 0.000156, the upper bound of the standard deviation of the error on chloride measurements calculated by Bonnet et al. (2017). Moreover, the lower the chloride content, the 
smaller the standard deviation. This observation may be accounted for by the fact that high chloride content is affected by a combination of several factors, which are very changeable along the beam due to the environment or to the heterogeneity of concrete during processing (vibration). The coefficient of variation is similar on both sides with most values within the range 0.25-0.35, save near the beam surface (Fig. 5b). This confirms an interesting statistical property for probabilistic modelling: the higher the chloride content, the higher the uncertainty. Duprat (2007) has shown that a high degree of uncertainty combined with some environmental parameters makes the chloride intake unpredictable. Chloride content values, on the other hand, are higher on the sheltered side because the concrete beam stands in a confined environment, highly loaded with salt spray. Chloride ions are trapped beneath the slab.

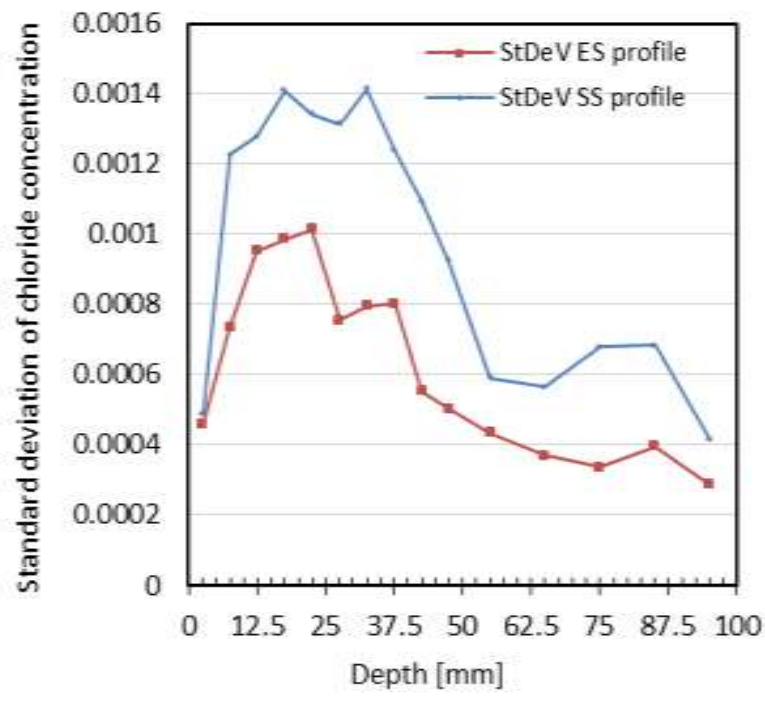

a)

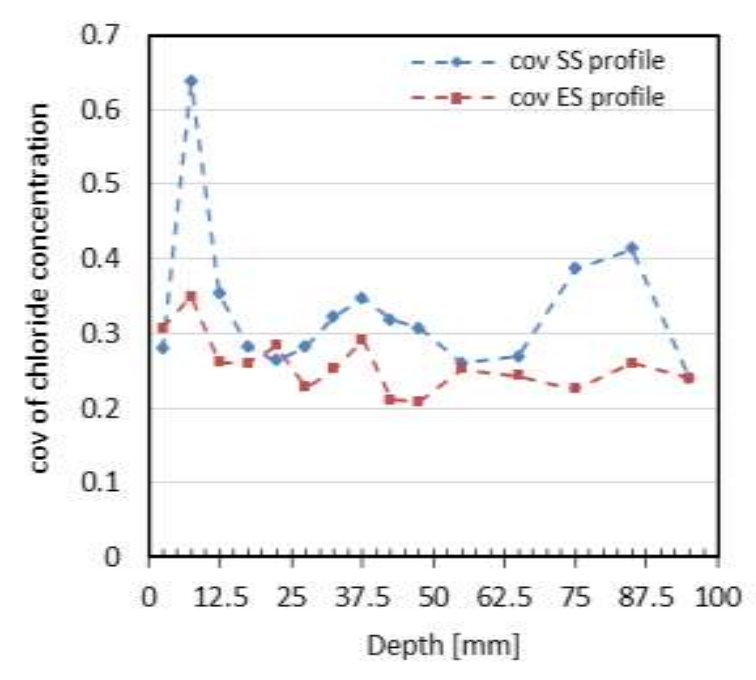

b)

Fig. 5: a) Standard Deviation (StDev) and b) coefficient of variation (COV) for chloride content for both exposures

3.2. Analytical model for diffusion law

In a marine environment, concrete can be considered as almost saturated. Indeed, the concrete used for the studied beam was casted in-situ. Thus, it was initially saturated and persistently exposed to high RH. RH, superior to $80 \%$, as shown in Table 2 was measured according to a national meteo station located nearby the beam but not so closed to the sea water as this one. Moreover the beam is submitted to water coming from splashing and/or rain. Besides, the pore network of the cement matrix is very thin. Baroghel-Bouny et al. (1999) explained that in this case the water displacement into concrete is low and can be described by a diffusion equation. 
. Thus, chloride ingress is modelled using Fick's diffusion model except near the surface and it is applied to fit the experimental chloride profiles.

For a homogeneous concrete, a constant surface content and a one- dimensional diffusion into a semi-infinite space, Fick's second law is expressed as:

$C(x, t)=C_{0}+\left(C_{s}-C_{0}\right) \operatorname{erfc}\left(\frac{x}{2 \sqrt{D t}}\right)$

where $C$ is the chloride content at a depth of $\mathrm{x}(\mathrm{m})$ after time $t(\mathrm{~s}) ; C_{0}\left(\mathrm{~kg}_{\mathrm{Cl}-} / \mathrm{kg}_{\text {concrete }}\right)$ the initial chloride content in concrete before exposure, $C_{s}\left(\mathrm{~kg}_{\mathrm{Cl}} / \mathrm{kg}_{\text {concrete }}\right)$ the chloride content at the surface and $\mathrm{D}\left(\mathrm{m}^{2} / \mathrm{s}\right)$ the diffusion coefficient.

The initial chloride content $C_{0}$ is obtained from eight samples at a depth of $200 \mathrm{~mm}$, which is considered distant enough from the surface to be representative of uncontaminated concrete. A very low negligible coefficient of variation (less than $2 \%$ ) is obtained with a mean value $C_{0}=0.001019 \mathrm{~kg}_{\mathrm{Cl}-/} \mathrm{kg}_{\text {concrete }}$, a maximum value $=0.001066$

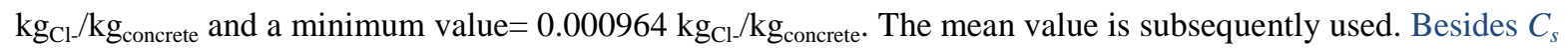
and $D$ are not time dependant in the paper, as it was done by (Chalee et al., 2009; Tadayon et al., 2016; Valipour et al., 2013), since all the samples have been taken from the same beam at the same age of 28 years old.

Moreover it was showm by Ben Fraj et al. (2012) that the diffusion coefficient decreases particularly in the first few months. The values for $C_{s}$ and $D$ were provided simultaneously by fitting the experimental profiles with Eq. 1 and were obtained by iteration using the Mathematica software with the least square minimization method

\subsection{Fitting method}

$C_{0}$ being known, the estimation of parameters $\mathrm{C}_{\mathrm{s}}$ and $\mathrm{D}$ of Fick's second law by fitting the experimental chloride profiles implies that these profiles have a monotonic decreasing shape. This is not, however, the case near the concrete surface where the first few centimetres present a high positive chloride gradient (Fig. 4). That is why discarding the first few centimetres below the surface is a commonly used technique (Chalee et al., 2009; Pang and Li, 2016). Da Costa et al. (2013) specify that the aim in doing this is to eliminate lixiviation effect.

Moreover, Fig. 6a shows that peak positions (the depth corresponding to the maximal chloride concentration) occurs at different depths between $12.5 \mathrm{~mm}$ and $37.5 \mathrm{~mm}$ with a maximum occurrence within the range $12.5 \mathrm{~mm}$ $-22.5 \mathrm{~mm}$. The objective of the following section is to examine the effect of pre-treatment (discarding of experimental data close to the surface) on the estimation of the Fick's law parameters. We will compare some 


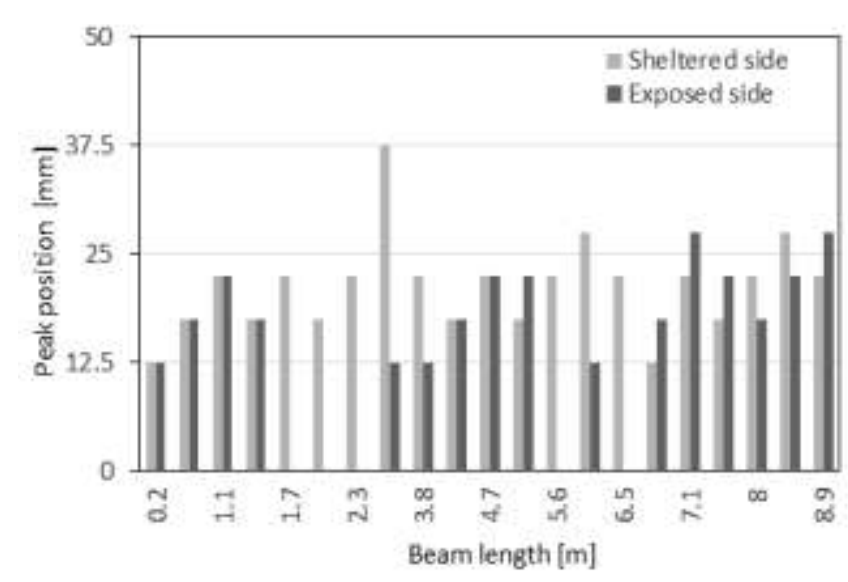

a)

Fig. 6: a) Distribution of peak positions (relative to the concrete surface) along the beam and b) Frequency of the peak positions

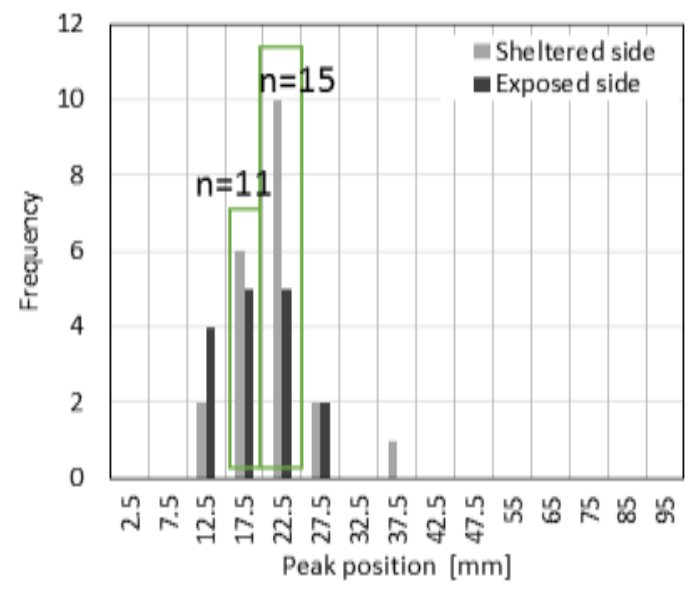

b)

\section{The three different experimental data pre-treatments studied here are now described:}

- $\quad$ In the first case, called "reference case", the treated profiles start from the real peak value that varies from a sample to another (no assumption is required). This method, where the peak position is assumed to be a random variable, is in better agreement with the real evolution of data. The trend, indeed, is a decreasing one (Bastidas et al, 2011, Nilsson et al., 2010). The peak value position varies within the range $12.5 \mathrm{~mm}-37.5 \mathrm{~mm}$ (Fig. 6). The pre-treatment of the experimental profiles is then carried out on an individual basis.

The two other treatments can be carried out on a systematic basis, relying, however, on the assumption of the peak position, which is assumed here to be deterministic:

- In the second case "15-mm discarded case", all data from the first $15 \mathrm{~mm}$ below the concrete surface are discarded. All the profiles start with the data at abscissa $17.5 \mathrm{~mm}$, which corresponds to a recurrent frequency peak depth for both exposed and sheltered sides ( $n=11$ in Fig. 6b). Moreover, the maximum absolute deviation between the real peak value (corresponding to the starting point in the reference case-1) and the value at $17.5 \mathrm{~mm}$ is $0.0022 \mathrm{~kg}_{\mathrm{Cl}} / \mathrm{kg}_{\text {concrete }}$ for the sheltered side and $0.0012 \mathrm{~kg}_{\mathrm{Cl}} / \mathrm{kg}_{\text {concrete }}$ for the exposed side.

- In the third case" 20-mm discarded case", all data from the first $20 \mathrm{~mm}$ below the concrete surface are discarded. The profiles here start at abscissa $22.5 \mathrm{~mm}$, which is the highest peak position frequency for both the sheltered and the exposed sides ( $\mathrm{n}=15$ for SS and 5 for ES in Fig. 6b). Moreover, the maximum absolute 
deviation between the real peak value and the value at $22.5 \mathrm{~mm}$ is $0.0014 \mathrm{~kg}_{\mathrm{Cl}} / \mathrm{kg}_{\text {concrete }}$ for the sheltered side and $0.0015 \mathrm{~kg}_{\mathrm{Cl}} / \mathrm{kg}_{\text {concrete }}$ for the exposed side.

\section{Results and discussion}

4.1. Preliminary comparison of the three pre-treatments The 37 experimental profiles are fitted using Fick's second law (Eq. 1) with the three pre-treatments to estimate $C_{s}$ and $D$ parameters. The main trends emerging from the results are discussed on the basis of the study of three profiles. Fig. 7 illustrates the fitting for three profiles with different real peak positions: $12.5 \mathrm{~mm}$ (profile 1ES), $17.5 \mathrm{~mm}$ (profile 14ES) and $22.5 \mathrm{~mm}$. (profile 4ES). The analysis of the shape of the curves, which can indicate the trend for (i) $\mathrm{C}_{\mathrm{s}}$ and (ii) $\mathrm{D}$, is then conducted. The quantitative results are displayed in Table 4 where the relative error $(\mathrm{RE})$ is defined as

$$
\mathrm{RE}=\left(\mathrm{y}-\mathrm{y}_{\mathrm{ref}}\right) / \mathrm{y}_{\mathrm{re}} \mathrm{f}
$$

where $y$ is $C_{s}$ or $D$ for the two pre-treatment cases (discarded $15 \mathrm{~mm}$ and $20 \mathrm{~mm}$, respectively), $\mathrm{y}_{\text {ref }}$ is $C_{s}$ or $D$ for the reference case.

(i) The estimation of the surface chloride content is first examined. For most specimens, pre-treatments 2 and 3 underestimate $\mathrm{C}_{\mathrm{s}}$. Moreover, the error is even greater when the real peak position at $22.5 \mathrm{~mm}$ is approximated by discarding the first $15 \mathrm{~mm}$ (Fig. 7c). At this point, it can be concluded that the case where points situated before the real peak position are discarded, increases the error contrary to the case where they are discarded beyond the real peak position (Fig. 7a and Fig. 7b versus Fig. 7c)

Song et al. (2008) give two reasons to explain the problem of the determination of $C_{s}$ : first, the composition of the concrete skin may be different from that of concrete inside the structure and second, the effects of some phenomena like the reaction between the concrete surface and the surrounding environment. On this basis, it can be concluded that the individual treatment respects the chloride intake capacity for each sample/position.

(i) The diffusion coefficient estimation is then discussed because it is one of the main parameters for assessing material performances as regards chloride penetration (da Costa et al., 2013). For most specimens here also, pre-treatments 2 and 3 overestimate D with a significant relative error. The result is a shortened predicted service life and increased maintenance costs (Bastidas and Schoefs, 2012) because of early scheduled repair operations. 

the same as those obtained for ES profiles 1, 4 and 14. The overall detail of the results is presented in Section

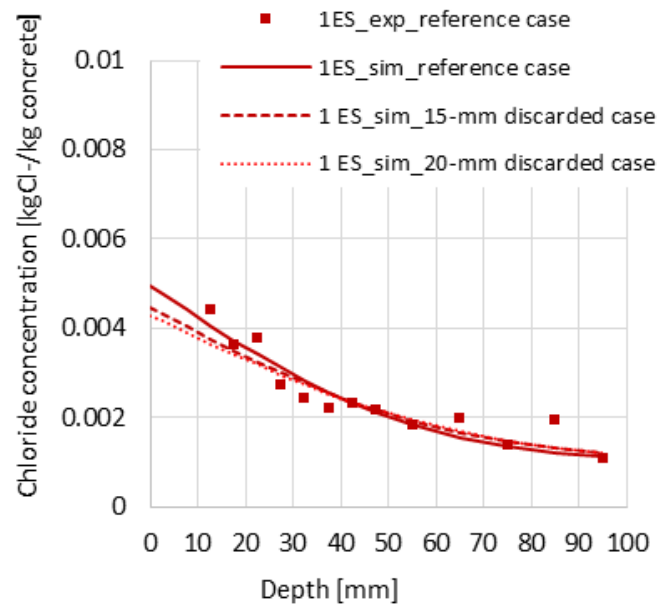

a)

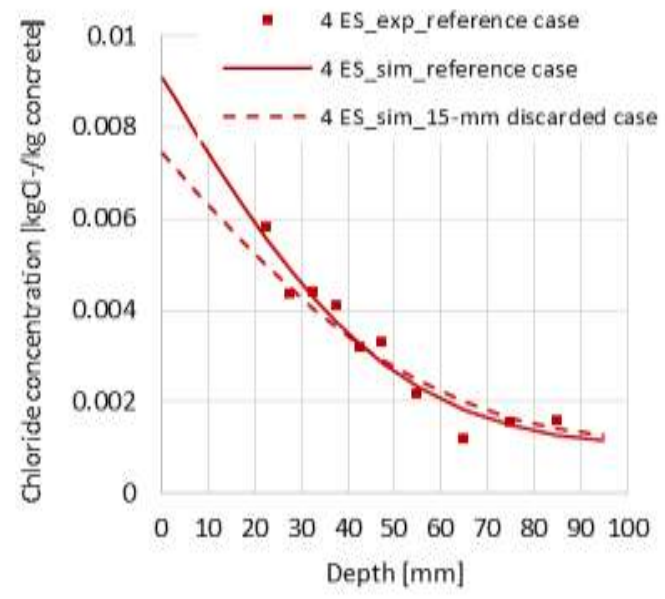

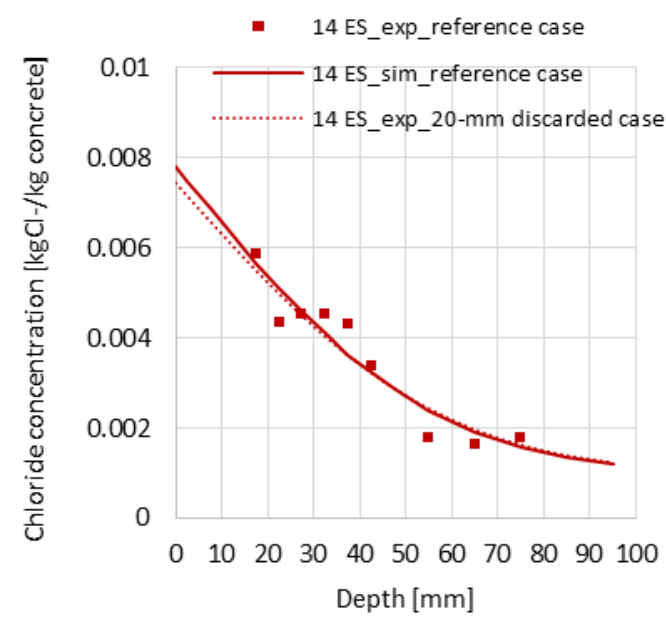

b)

Fig. 7: Fitting model results for chloride profiles showing a peak at a) $12.5 \mathrm{~mm}$ (sample $1 \mathrm{ES})$, b) 17.5 mm (sample 14ES), and c) $22.5 \mathrm{~mm}$ (sample 4ES)

Table 4: Estimated values of $C_{s}\left(\mathrm{~kg} \mathrm{Cl}_{\mathrm{Cl}} / \mathrm{kg}\right.$ concrete $)$ and relative error (RE) with the reference case for profiles 1,4 and 14

\begin{tabular}{|c|c|c|c|c|c|c|}
\hline & \multicolumn{2}{|c|}{$\begin{array}{c}\text { Peak at } 12.5 \mathrm{~mm} \\
\text { Fig. } 7 \mathrm{a}\end{array}$} & \multicolumn{2}{|c|}{$\begin{array}{c}\text { Peak at } 17.5 \mathrm{~mm} \\
\text { Fig. } 7 \mathrm{~b}\end{array}$} & \multicolumn{2}{|c|}{$\begin{array}{c}\text { Peak at } 22.5 \mathrm{~mm} \\
\text { Fig. } 7 \mathrm{c}\end{array}$} \\
\hline & $C_{s}$ & RE & $C_{s}$ & RE & $C_{s}$ & $\mathrm{RE}$ \\
\hline Reference case & 0.00495 & $0 \%$ & 0.00779 & $0 \%$ & 0.00908 & $0 \%$ \\
\hline 15-mm discarded case & 0.00446 & $9.9 \%$ & 0.00779 & $0 \%$ & 0.00742 & $18.3 \%$ \\
\hline 20-mm discarded case & 0.00428 & $13.4 \%$ & 0.00743 & $4.5 \%$ & 0.00908 & $0 \%$ \\
\hline
\end{tabular}

Table 5: Estimated values of $D\left(10^{-12} \mathrm{~m}^{2} / \mathrm{s}\right)$ and relative error (RE) with the reference case for profiles 1,4 and 14

Peak at $12.5 \mathrm{~mm} \quad$ Peak at $17.5 \mathrm{~mm} \quad$ Peak at $22.5 \mathrm{~mm}$




\begin{tabular}{lcccccc}
\hline & $D$ & $\mathrm{RE}$ & $D$ & $\mathrm{RE}$ & $D$ & $\mathrm{RE}$ \\
\cline { 2 - 7 } Reference case & 1.08 & $0 \%$ & 1.06 & $0 \%$ & 0.87 & $0 \%$ \\
\hline 15-mm discarded case & 1.36 & $25.4 \%$ & 1.06 & $0 \%$ & 1.17 & $33.7 \%$ \\
\hline 20-mm discarded case & 1.48 & $36.1 \%$ & 1.14 & $7.6 \%$ & 0.87 & $0 \%$ \\
\hline
\end{tabular}

4.2. Effects on peak position

In order to quantify the sensitivity of $C_{s}$ and $D$ to treatment methods, the relative error (Eq. 2) is plotted vs. the distance to the peak position $N_{x}$ (Eq. 3).

$$
N_{x}=x-x_{r e f}
$$

where, $x$ is the depth as displayed in Fig. $6 \mathrm{~b}$ ( $x$ takes the value $17.5 \mathrm{~mm}$ for the ' 15 -mm discarded' case and 22.5 $\mathrm{mm}$ for the "20-mm discarded case" and $x_{\text {ref }}$ is the real abscissa of the peak (reference case).

If $N_{x}>0$, the real peak position is closer to the surface than $17.5 \mathrm{~mm}$ (case 2) or $22.5 \mathrm{~mm}$ (case 3). Otherwise $\left(N_{x}<0\right)$, the peak occurs deeper than $17.5 \mathrm{~mm}$ or $22.5 \mathrm{~mm}$.

Fig. 8 shows that when $N x>0$, the values of $C_{s}$ are underestimated by $60 \%$ when the overestimation of $D$ is 2 times greater. A similar trend is observed when $N x<0$. In other words, $C_{s}$ is underestimated when $D$ is overestimated.

Those results highlight the significant effect of the mathematical expression of the model on the assessment of the estimated parameters $C_{s}$ and $D$.

This affects the prediction of maintenance and repair operations: surface chloride content represents the extent of the aggressive action of a marine environment on concrete structures and provides an important boundary condition for service life prediction and quantitative durability design of RC structures. 


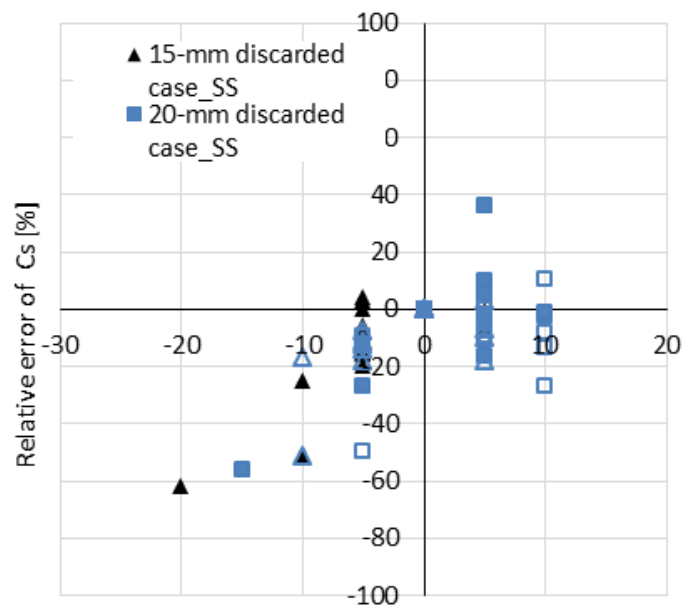

$\mathrm{Nx}[\mathrm{mm}]$

a)

Fig. 8: Relative error vs. $N_{x}$ for a) $C_{s}$ and b) $D$

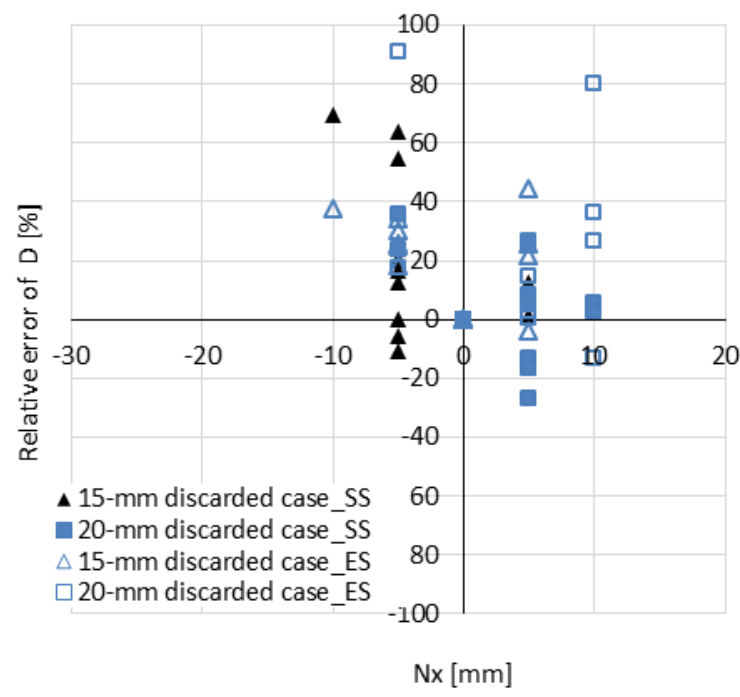

b)

4.3. Comparison of the estimated mean and standard deviations for $C_{s}$ and $D$ on the whole data base The previous section underlined the effect of an individual pre-treatment of the experimental chloride profiles (reference case) on the relative error. In this section, a quantitative analysis is carried out to highlight the impact of pre-treatment on the mean and standard deviations of the estimated parameters. The values of the chloride surface contents and diffusion coefficients along the beam, estimated using the three pre-treatment methods, are given in Fig. 9. The real position of the peak is also plotted on the same figure (solid line). The scatter of the points is more pronounced on the sheltered side and will be exhaustively discussed below. It should be noted that, from a statistical point of view, this could be partly related to the number of points used to fit the experimental chloride profiles. All the curves have 12 points each (starting from $2.5 \mathrm{~mm}$ to $95 \mathrm{~mm}$ ). However, when the peak occurs deep from the surface (deeper than $22.5 \mathrm{~mm}$ ), few points only remain for fitting. For the 15-mm and 20-mm discarded cases, the number of points is 12 and 11 , respectively.

$\mathrm{C}_{\mathrm{s}}$ is first examined for both exposures (Fig. 9a, right side and Fig. 9b, left side). Most of $C_{s}$ values are coherent between the different treatments for both exposures. Moreover, the trend observed in the previous section is confirmed: the deeper the peak, the higher the error is (unde-estimation) when discarding points before $15 \mathrm{~mm}$. We observe that the peak occurs principally at $22.5 \mathrm{~mm}$ for the sheltered side (10 profiles / total of 21 profilesSS but only on five profiles for the exposed side (total of 16 profiles-ES). The total mean value of $C_{s}$ on the sheltered side is $0.00802 \mathrm{~kg} \mathrm{Cl} / \mathrm{kg}_{\text {concrete }}\left(\min =0.00731 \mathrm{~kg}_{\mathrm{Cl}} / \mathrm{kg}_{\text {concrete }} ; \max =0.00856 \mathrm{~kg} \mathrm{Cl}_{\mathrm{Cl}} / \mathrm{kg}_{\text {concrete }}\right)$ whereas the mean value of $C_{s}$ on the exposed side is $0.0054 \mathrm{~kg} \mathrm{Cl} / / \mathrm{kg}_{\text {concrete }}\left(\min =0.00514 \mathrm{~kg} \mathrm{Cl}_{\mathrm{Cl}} / \mathrm{kg}\right.$ concrete; $\max =0.00576 \mathrm{~kg}$ $\mathrm{Cl} / \mathrm{kg}$ concrete). The values obtained are in accordance with those found in the literature for real structures in a 
marine environment with comparable exposures and investigation periods: $C_{s}$ can vary between $0.002 \mathrm{~kg} \mathrm{Cl} / \mathrm{kg}$ concrete (33-year-old bridge- Table 1) (de Rincón et al., 2004) and $0.0078 \mathrm{~kg} \mathrm{cl} / \mathrm{kg}$ concrete (29-year-old offshore platform) (Medeiros-Junior et al., 2015).

Fig. 10 presents the mean values of $\mathrm{C}_{\mathrm{s}}$ (as histograms) and the standard deviation: both are higher on the sheltered side than on the exposed side. The sheltered side refers to a confined environment with high relative humidity, which is more affected by sea water through splashing. Consequently, more spray is trapped under the beam relative to the exposed side, which is more subjected to weather variations. This is in accordance with Kenshel (2009) who explains the higher surface content values of $C_{s}$ on the sheltered side up to three times by the wash-down conditions due to driving rain on the exposed side.
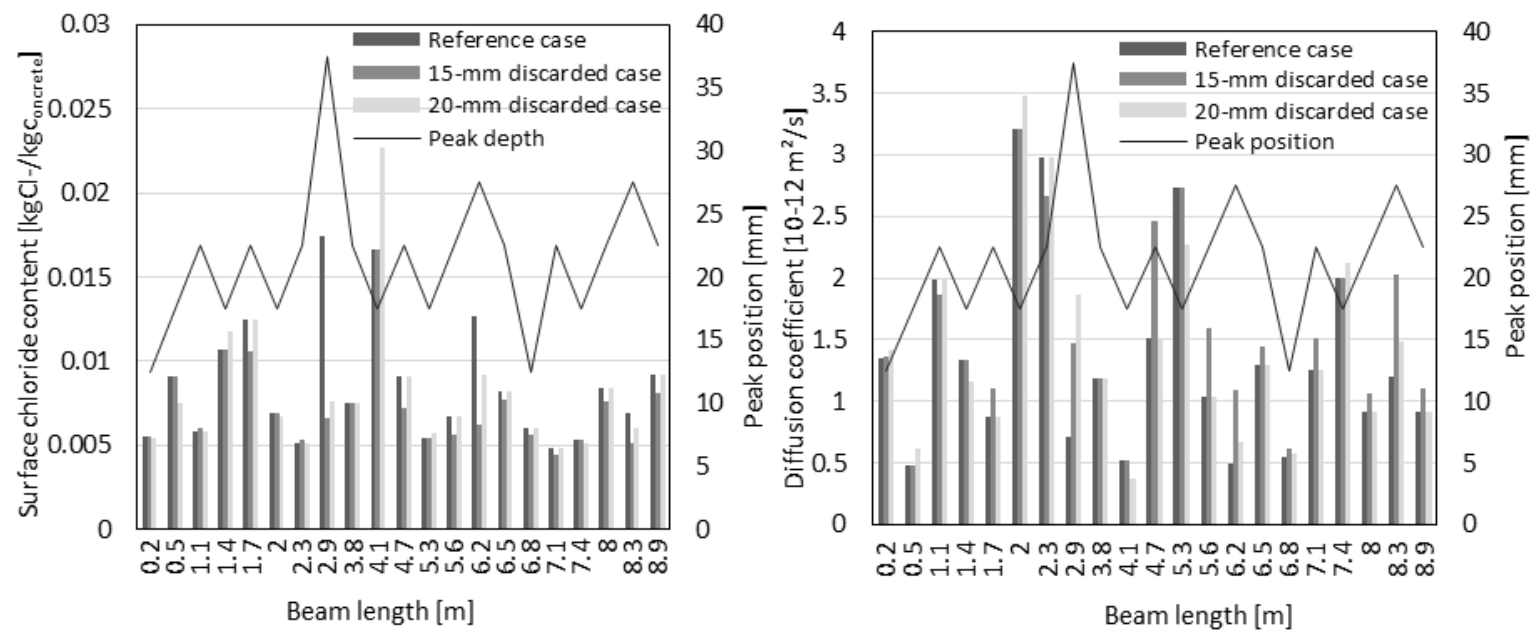

a)sheltered side

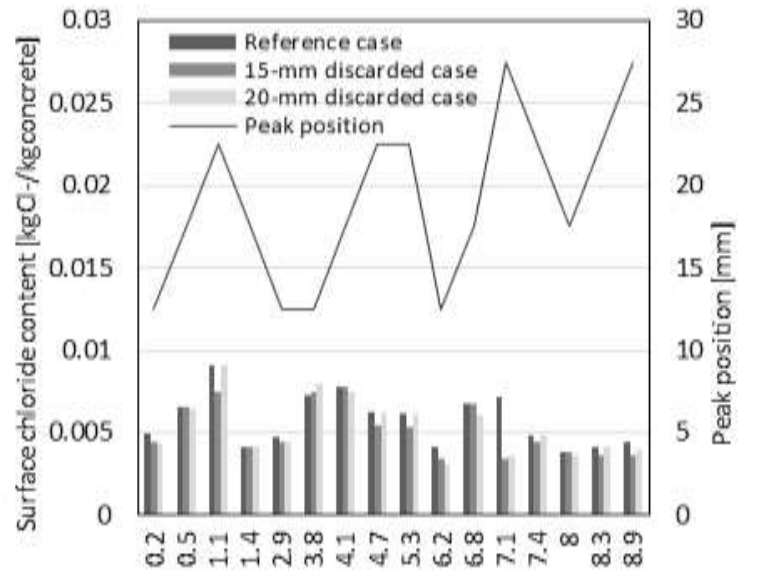

Beam length $[\mathrm{m}]$

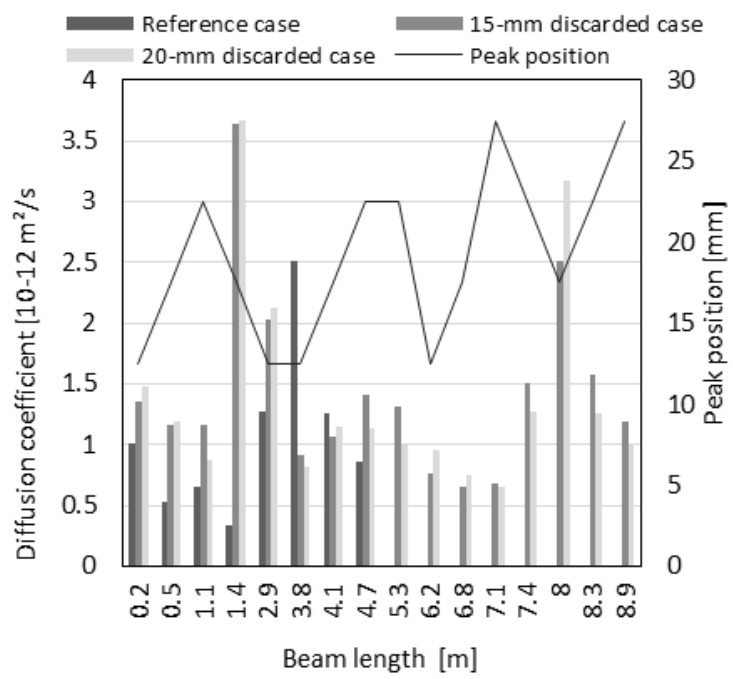

b) exposed side

Fig. 9: Variation of $\mathrm{C}_{\mathrm{s}}$ and $\mathrm{D}$ together with peak position (black curve) according to the set of analysis for a) the sheltered side and $b$ ) the exposed side 
The estimated values of $D$ for both exposures are then analysed (Fig. 9a and Fig. 9b- right side). The global mean value of $D$ is $1.45 \times 10^{-12} \pm 7.9 \times 10^{-13} \mathrm{~m}^{2} / \mathrm{s}$. Mean values are virtually the same for both sides of the beam (Fig. 10) and in accordance with those found in the literature for real structures in a marine environment: $D$ can vary between $2.75 \times 10^{-13} \mathrm{~m}^{2} / \mathrm{s}$ (case of a 25 -year-old offshore platform-Table 1) (da Costa et al., 2013) and $5.13 \times 10^{-12} \mathrm{~m}^{2} / \mathrm{s}$ (case of a 29-year-old offshore platform-Table 1) (Medeiros-Junior et al., 2015).

Again the importance of considering the real shape of the chloride profile with the real peak position must be pointed out. This allows more efficient determination of $C_{s}$ and $D$. These two deterioration parameters are the most significant as regards the initiation stage of structure service life as shown by(Kenshel, 2009).
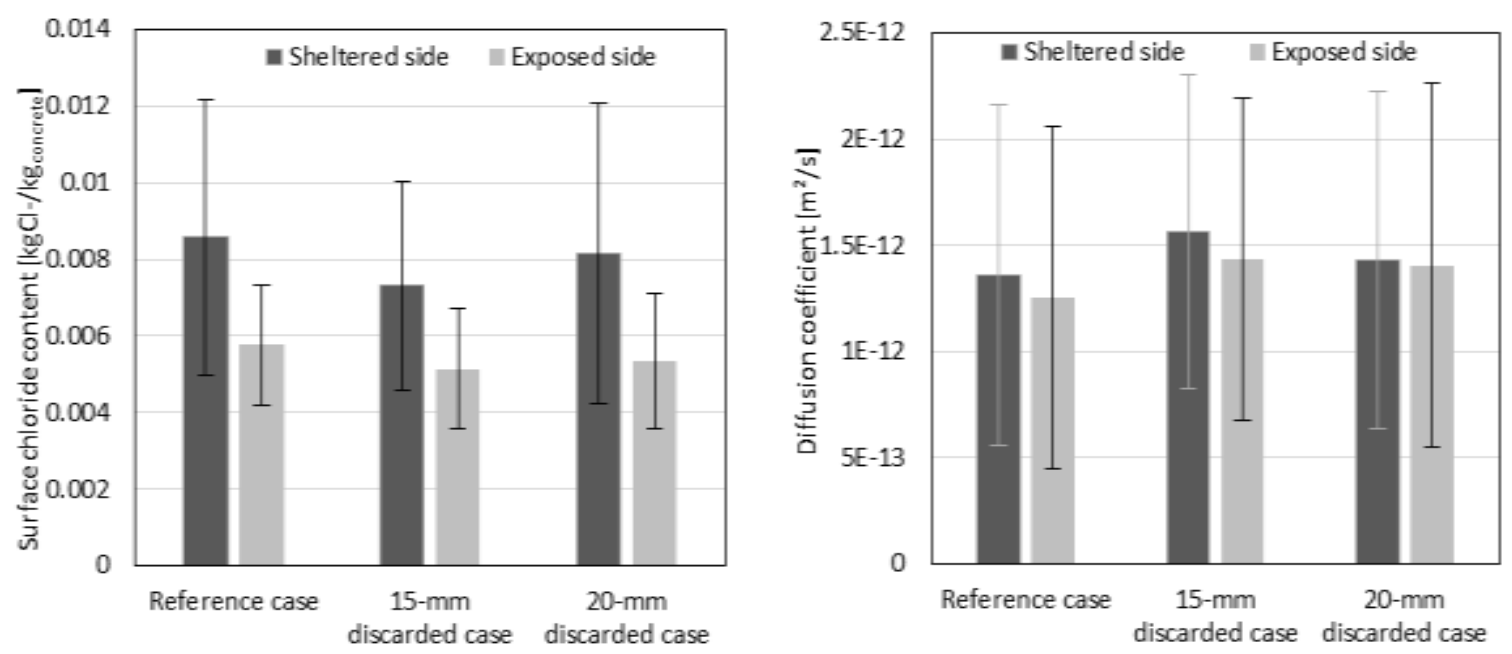

Fig. 10: Mean values (histograms) and standard deviations (error bars) for $\mathrm{C}_{\mathrm{s}}$ and $\mathrm{D}$ for both exposures

\subsection{Statistical analysis for the reference case}

The previous section underlined the need for an individual pre-treatment of the experimental chloride profiles (reference case). The present section, therefore, focuses on the reference case with the aim of producing a model for the estimated parameters of the Fick's diffusion model: 37 identified coefficients of $C_{s}$ and $D$ are available when combining sheltered and exposed side results. The scatter of points for $D$ and $C_{s}$ is assessed by computing their Coefficients of Variation $(\mathrm{CoV})\left(\right.$ Table 6): $D$ scattering is larger $(\mathrm{CoV}(\mathrm{D})=0.61)$ than $C_{s}$ one $\left(\mathrm{CoV}\left(\mathrm{C}_{\mathrm{s}}\right)=\right.$ 0.44), an expected result in view of Fig. 10 analysis. Moreover, those values are consistent with the data found in the literature: $\operatorname{CoV}(D)$ ranges from 0.38 to 0.69 and $\operatorname{CoV}\left(C_{s}\right)$ ranges from 0.31 to 0.83 (Table 6).

Table 6: Comparison between values found in the literature and experimental values of $\mathrm{CoV}(\%)$ for $C_{s}$ and $D$

\begin{tabular}{llc} 
& $C_{s}$ & $D$ \\
\hline Kenshel (2009) & 56 & 40 \\
\hline Pang and Li (2016) & 55 & 69 \\
\hline Berke and Hicks (1992) [ref (Kenshel, 2009)] & 40 & - \\
\hline
\end{tabular}




\begin{tabular}{|c|c|c|c|}
\hline Wood and Crerar (1997) [ref (Duprat, 2007) ] & & 63 & 38 \\
\hline Uji et al. (1990) [ref (Duprat, 2007) ] & & 83 & - \\
\hline Cramer et al. (2002) & & 51 & 57 \\
\hline Pritzl et al. (2015) & & 31 & 42 \\
\hline \multirow{3}{*}{ Actual Study } & $\mathrm{SS}$ & 42 & 59 \\
\hline & $\mathrm{ES}$ & 27 & 64 \\
\hline & Global (mean of SS and ES) & 44 & 61 \\
\hline
\end{tabular}

It clearly appears that these parameters should be modelled by random variables. Fig.8 has shown that $D$ and $C_{s}$ are not independent because they come both from the regression of the chloride profile using Fick's $2^{\text {nd }}$ law. Further $C_{s}$ does not come from a direct measurement on the concrete surface but it comes rather from an extrapolation of chlorides in the material (starting from $7.5 \mathrm{~mm}$ to $37.5 \mathrm{~mm}$ as shown in fig 6) to the abscissa $\mathrm{x}=0 \mathrm{~mm}$.

We now examine their statistical dependence by plotting the scatter diagram of $C_{s}$ and $\mathrm{D}$ in Fig. 11. It can be noticed that, whatever the exposure, for a tight range of $C_{s}$ (around $0.004 \mathrm{~kg}_{\mathrm{Cl}} / \mathrm{kg}_{\text {concrete }}$ ), $D$ ranges from $0.36 \times 10^{-12}$ to $3.67 \times 10^{-12} \mathrm{~m}^{2} / \mathrm{s}$. This trend clearly demonstrates that $C_{s}$ and $D$ are correlated when identified from Fick's $2^{\text {nd }}$ law. Conversely, a joint distribution of these parameters should be used when modeling $C_{s}$ and $D$ as random variables and propagating uncertainties through the same model. However, this rule is not general. Note that physically, $C_{s}$ depends not only on the environmental conditions but also on the composition of concrete due to the chloride fixation capacity of the binder, which in turn depends on its free chloride content and so on its diffusivity. Indeed $C_{s}$ is determined by fitting and using the experimental chloride contents close to the surface.

However until now, no data are available and our proposition is only valuable for Fick's second law model.

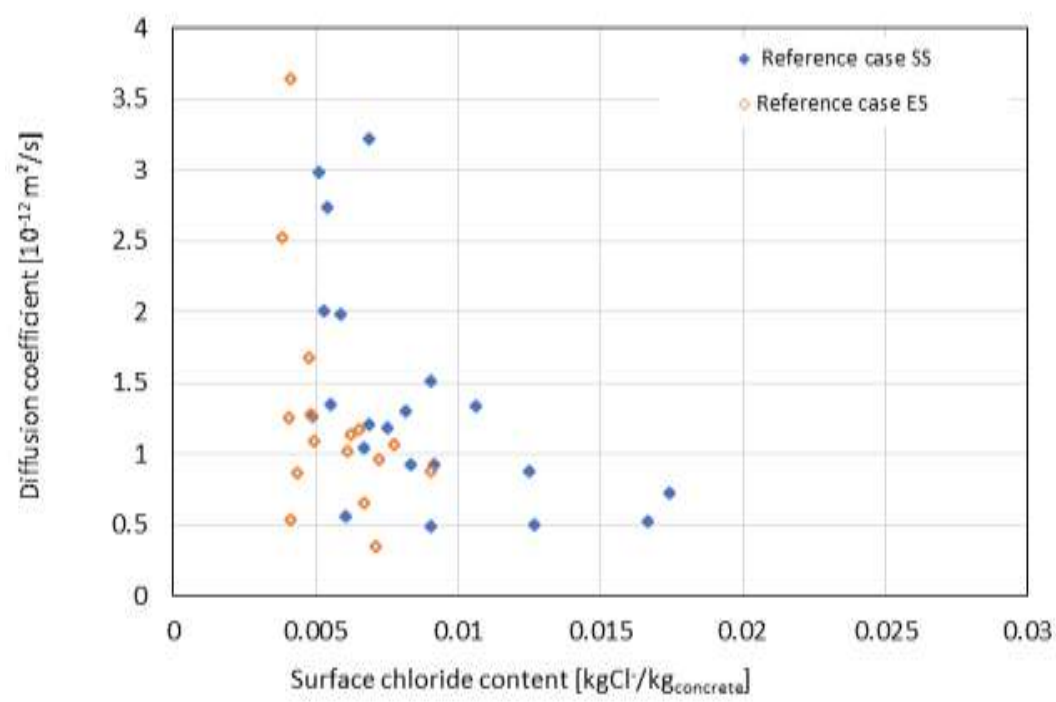

Fig. 11: $C_{s}$ and $D$ scatter diagram for the both exposures (reference case) 
Probabilistic modelling last key step consists in the assessment of marginal probability density functions (pdf).

The probabilistic distribution and fitting with a lognormal pdf according to the maximum likelihood estimate are plotted in Fig. 12. As suggested in the literature, $C_{s}$ and $D$ are well fitted by a lognormal pdf (Duprat, 2007; Li et al., 2015).The lognormal parameters used in this study are given in Fig. 12. Applying a lognormal pdf for the results obtained appears relevant because both parameters are positive. Moreover, their distribution is dissymmetric as shown in Fig. 12.
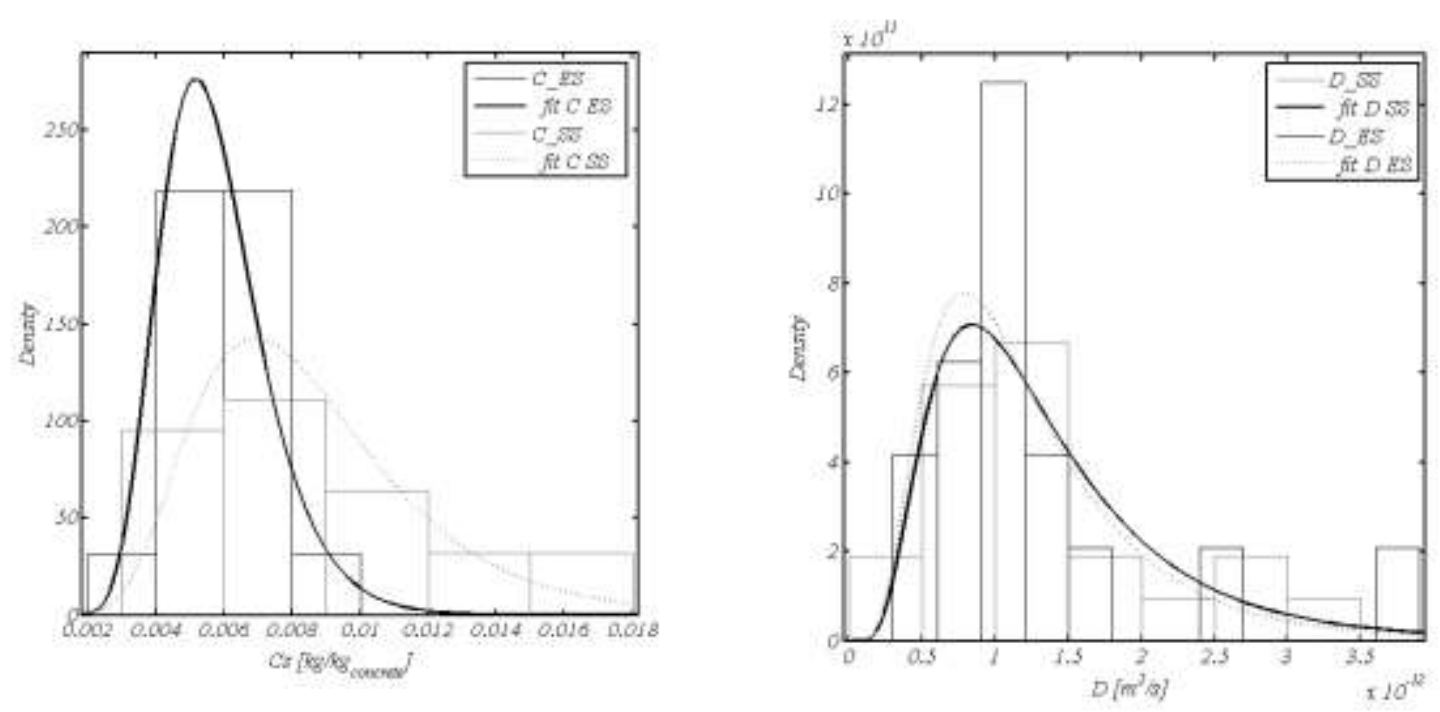

Fig. 12: Lognormal pdf of $\mathrm{C}_{\mathrm{s}}$ and $\mathrm{D}$ for the reference case

Table 7: Lognormal pdf parameters for $\mathrm{C}_{\mathrm{s}}$ and $\mathrm{D}$ (reference case)

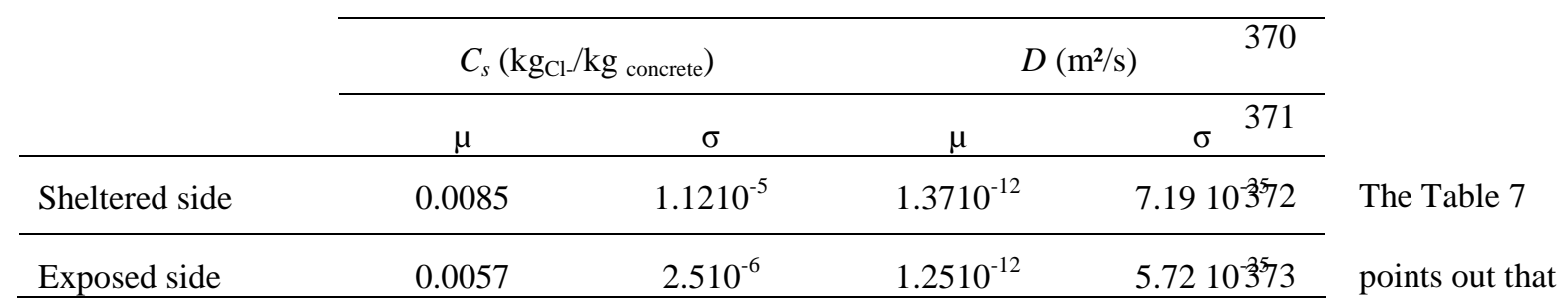

the mean value of $C_{s}$ on the sheltered side is 1.5 times higher than on the exposed side. This result is in accordance with the global observations conducted on the field data in Fig. 4 and with the results obtained by Kenshel (2009) where $C_{s}$ is up to three times higher on the north side than on the south side with regard to the prevailing wind.

\section{Conclusion}

The present study has been conducted to examine a 28 -year-old reinforced concrete structure in a marine splash zone. An important set of chloride data is studied, which constitutes a substantial material for spatial variability modelling. Chloride profiles have been measured every $30 \mathrm{~cm}$ on the same beam line with two different exposure situations: a sheltered side (SS) and an exposed side (ES). 
The following conclusions can be drawn:

- 37 workable chloride profiles (21 for SS and 16 for ES) collected along a beam located in an estuary area are studied. Chloride content values are higher on the sheltered side. This can be explained by the fact that the sheltered side is also the lee side and is highly moisture laden. On this side, saline spray is trapped and the contact with seawater is greater due to splashing.

- The experimental chloride profiles are fitted using Fick's second law in order to estimate its parameters: the surface content $C_{s}$ and the diffusion coefficient $D$. Three pre-treatments of these profiles are carried out: a "reference case" (individual treatment), a "15-mm discarded" case and a "20-mm discarded" case (generic treatments). The reference case results underline the sensitivity of the parameters to the first point corresponding to the maximum content position. When a generic method is applied (systematic discarding of the first few millimetres below the surface), as is the case in the literature, $C_{s}$ is underestimated whereas $D$ is overestimated. Consequently, the rate of error relating to the reference case is around $50 \%$ for $C_{s}$ and can reach $100 \%$ for $D$.

- The reference case is used for the statistical study. The computation of the coefficient of variation reveals that $\mathrm{D}$ scattering is larger $(\mathrm{CoV}=59 \%$ for $\mathrm{SS}$ and $\mathrm{CoV}=64 \%$ for $\mathrm{ES})$ than $\mathrm{Cs}$ one $(\mathrm{CoV}=$ $42 \%$ for $\mathrm{SS}$ and $\mathrm{CoV}=27 \%$ for $\mathrm{ES}$ ) and that their values are consistent with the data found in the literature. Moreover, the global mean value of $C_{s}$ is $0.7 \% \mathrm{~kg}_{\mathrm{Cl}-/} \mathrm{kg}_{\text {concrete }}$ (calculated for both sheltered and exposed sides) and corresponds to a certain risk of corrosion according to the risk classification proposed by Bamforth (Bamforth, 1996)

- $\quad$ Finally $C_{s}$ and $D$ have a dissymmetric distribution and are well fitted with a lognormal distribution.

These results underline the importance of the individual treatment of field chloride profiles for an accurate determination of $C_{s}$ and $D$. Reducing uncertainties of those key parameters inputs for corrosion damage detection allows the development of a probabilistic-based performance prediction tool that can be used to predict accurately the time to corrosion initiation and hence the optimal time for repair/maintenance intervention of reinforced concrete structures in a marine environment. Furthermore as the chloride profiles are made from a destructive method which is a tedious procedure, it is interesting for the owner to optimize the number of cores. This study done on 30 profiles extracted at a distance of $30 \mathrm{~cm}$ from each other would allow optimizing the number of coring. 
The authors would like to acknowledge and thank the harbour of Nantes-Saint Nazaire "Grand Port de Nantes

Saint Nazaire", especially Mr. Laurent Suire and Mr. Pascal Lijours, for supporting this study, and Mr. Michel

Roche for his technical support

\section{References}

Andrade, C., Díez, J.M., Alonso, C., 1997. Mathematical Modeling of a Concrete Surface "Skin Effect" on Diffusion in Chloride Contaminated Media. Advanced Cement Based Materials 6, 39-44. https://doi.org/10.1016/S1065-7355(97)00002-3

Bamforth, P.B., 1996. Definition of exposure classes and concrete mix requirements - Technische Informationsbibliothek (TIB), in: Corrosion of Reinforcement in Concrete Construction. Presented at the International symposium; 4th, Corrosion of reinforcement in concrete construction, Cambridge, pp. $176-190$.

Baroghel-Bouny, V., Mainguy, M., Lassabatere, T., Coussy, O., 1999. Characterization and identification of equilibrium and transfer moisture properties for ordinary and high-performance cementitious materials. Cement and Concrete Research 29, 1225-1238. https://doi.org/10.1016/S0008-8846(99)00102-7

Bastidas-Arteaga, E., Chateauneuf, A., Sánchez-Silva, M., Bressolette, P., Schoefs, F., 2011. A comprehensive probabilistic model of chloride ingress in unsaturated concrete. Engineering Structures 33, 720-730. https://doi.org/10.1016/j.engstruct.2010.11.008

Ben Fraj, A., Bonnet, S., Khelidj, A., 2012. New approach for coupled chloride/moisture transport in nonsaturated concrete with and without slag. Construction and Building Materials 35, 761-771. https://doi.org/10.1016/j.conbuildmat.2012.04.106

Berke, N.S., Hicks, M.C., 1992. Estimating the Life Cycle of Reinforced Concrete Decks and Marine Piles Using Laboratory Diffusion and Corrosion Data. https://doi.org/10.1520/STP19764S

Bonnet, S., Schoefs, F., salta, M., 2017. Sources of uncertainties for total chloride profile measurements in concrete: quantization and impact on probability assessment of corrosion initiation. European Journal of Environmental and Civil Engineering. https://doi.org/doi.org/10.1080/19648189.2017.1375997

Chalee, W., Jaturapitakkul, C., Chindaprasirt, P., 2009. Predicting the chloride penetration of fly ash concrete in seawater. Marine Structures 22, 341-353. https://doi.org/10.1016/j.marstruc.2008.12.001

Chaussadent, T., Arliguie, G., 1999. AFREM test procedures concerning chlorides in concrete: Extraction and titration methods. Mat. Struct. 32, 230-234. https://doi.org/10.1007/BF02481520

Cramer, S.D., Covino Jr., B.S., Bullard, S.J., Holcomb, G.R., Russell, J.H., Nelson, F.J., Laylor, H.M., Soltesz, S.M., 2002. Corrosion prevention and remediation strategies for reinforced concrete coastal bridges. Cement and Concrete Composites, CORROSION AND CORROSION MONITORING 24, 101-117. https://doi.org/10.1016/S0958-9465(01)00031-2

da Costa, A., Fenaux, M., Fernández, J., Sánchez, E., Moragues, A., 2013. Modelling of chloride penetration into non-saturated concrete: Case study application for real marine offshore structures. Construction and Building Materials 43, 217-224. https://doi.org/10.1016/j.conbuildmat.2013.02.009

de Rincón, O.T., Castro, P., Moreno, E.I., Torres-Acosta, A.A., de Bravo, O.M., Arrieta, I., García, C., García, D., Martínez-Madrid, M., 2004. Chloride profiles in two marine structures-meaning and some predictions. Building and Environment 39, 1065-1070. https://doi.org/10.1016/j.buildenv.2004.01.036

de Vera G., Climent M. A., Viqueira E., Antón C., López M. P., 2015. Chloride Penetration Prediction in Concrete through an Empirical Model Based on Constant Flux Diffusion. Journal of Materials in Civil Engineering 27, 04014231. https://doi.org/10.1061/(ASCE)MT.1943-5533.0001173

Duprat, F., 2007. Reliability of RC beams under chloride-ingress. Construction and Building Materials 21, 1605-1616. https://doi.org/10.1016/j.conbuildmat.2006.08.002

Fédération International du Béton, 2006. Model code for service life design. Bulletin 34. Lausanne:fib. 
Guo, A., Li, H., Ba, X., Guan, X., Li, H., 2015. Experimental investigation on the cyclic performance of reinforced concrete piers with chloride-induced corrosion in marine environment. Engineering Structures 105, 1-11. https://doi.org/10.1016/j.engstruct.2015.09.031

Hilsdorf, H., Kropp, J., 2004. Performance Criteria for Concrete Durability. CRC Press.

Kenshel, O.M., 2009. Influence on Spatial Variability on Whole Life Management of Reinforced Concrete Bridges. Trinity College.

Li, J., Shao, W., 2014. The effect of chloride binding on the predicted service life of RC pipe piles exposed to marine environments. Ocean Engineering 88, 55-62. https://doi.org/10.1016/j.oceaneng.2014.06.021

Li, Q., Li, K., Zhou, X., Zhang, Q., Fan, Z., 2015. Model-based durability design of concrete structures in Hong Kong-Zhuhai-Macau sea link project. Structural Safety 53, 1-12. https://doi.org/10.1016/j.strusafe.2014.11.002

Li, Q., Rao, J., Fazio, P., 2009. Development of $\{\mathrm{HAM}\}$ tool for building envelope analysis. Building and Environment 44, 1065-1073. http://dx.doi.org/10.1016/j.buildenv.2008.07.017

Luping, T., Gulikers, J., 2007. On the mathematics of time-dependent apparent chloride diffusion coefficient in concrete. Cement and Concrete Research 37, 589-595. https://doi.org/10.1016/j.cemconres.2007.01.006

Mangat, P.S., Molloy, B.T., 1994. Prediction of long term chloride concentration in concrete. Materials and Structures 27, 338-346. https://doi.org/10.1007/BF02473426

Medeiros-Junior, R.A. de, Lima, M.G. de, Brito, P.C. de, Medeiros, M.H.F. de, 2015. Chloride penetration into concrete in an offshore platform-analysis of exposure conditions. Ocean Engineering 103, $78-87$. https://doi.org/10.1016/j.oceaneng.2015.04.079

Nguyen, P.T., Bastidas-Arteaga, E., Amiri, O., Soueidy, C.-P.E., 2017. An Efficient Chloride Ingress Model for Long-Term Lifetime Assessment of Reinforced Concrete Structures Under Realistic Climate and Exposure Conditions. Int J Concr Struct Mater 11, 199-213. https://doi.org/10.1007/s40069-017-0185-8

O’Connor, A.J., Kenshel, O., 2013. Experimental Evaluation of the Scale of Fluctuation for Spatial Variability Modeling of Chloride-Induced Reinforced Concrete Corrosion. Journal of Bridge Engineering 18, 3-14. https://doi.org/10.1061/(ASCE)BE.1943-5592.0000370

Pang, L., Li, Q., 2016. Service life prediction of RC structures in marine environment using long term chloride ingress data: Comparison between exposure trials and real structure surveys. Construction and Building Materials 113, 979-987. https://doi.org/10.1016/j.conbuildmat.2016.03.156

Pritzl, M.D., Tabatabai, H., Ghorbanpoor, A., 2015. Long-term chloride profiles in bridge decks treated with penetrating sealer or corrosion inhibitors. Construction and Building Materials 101, Part 1, 1037-1046. https://doi.org/10.1016/j.conbuildmat.2015.10.158

Recommendation for analysis of total chloride in concrete., 2006. . Materials and Structures 35, 583-585.

Song, H.-W., Lee, C.-H., Ann, K.Y., 2008. Factors influencing chloride transport in concrete structures exposed to marine environments. Cement and Concrete Composites 30, 113-121. https://doi.org/10.1016/j.cemconcomp.2007.09.005

Tadayon, M.H., Shekarchi, M., Tadayon, M., 2016. Long-term field study of chloride ingress in concretes containing pozzolans exposed to severe marine tidal zone. Construction and Building Materials 123, 611-616. https://doi.org/10.1016/j.conbuildmat.2016.07.074

Thomas, M.D.A., Matthews, J.D., 2004. Performance of pfa concrete in a marine environment-10-year results. Cement and Concrete Composites 26, 5-20. https://doi.org/10.1016/S0958-9465(02)00117-8

Uji, K., Matsuoka, Y., Maruya, T., 1990. Formulation of an equation for surface chloride content of concrete due to permeation of chloride. Corrosion of reinforcement in concrete. Papers presented at the third international symposium on "corrosion of reinforcement in concrete construction", belfry hotel, wishaw, warwickshire, MAY 21-24, 1990. Publication of: CICC Publications.

Valipour, M., Pargar, F., Shekarchi, M., Khani, S., Moradian, M., 2013. In situ study of chloride ingress in concretes containing natural zeolite, metakaolin and silica fume exposed to various exposure conditions in a harsh marine environment. Construction and Building Materials 46, 63-70. https://doi.org/10.1016/j.conbuildmat.2013.03.026 
Vennesland, P. by Ø., Climent, M.A., Andrade)**, C.A.R.T.C. 178-T. (Carmen, 2012. Recommendation of RILEM TC 178-TMC: Testing and modelling chloride penetration in concrete*. Materials and Structures 46, 337-344. https://doi.org/10.1617/s11527-012-9968-1

Wang, H.-L., Dai, J.-G., Sun, X.-Y., Zhang, X.-L., 2016. Characteristics of concrete cracks and their influence on chloride penetration. Construction and Building Materials 107, 216-225. https://doi.org/10.1016/j.conbuildmat.2016.01.002

Win, P.P., Watanabe, M., Machida, A., 2004. Penetration profile of chloride ion in cracked reinforced concrete. Cement and Concrete Research 34, 1073-1079. https://doi.org/10.1016/j.cemconres.2003.11.020

Wood, J.G.M., Crerar, J., 1997. Tay road bridge: Analysis of chloride ingress variability \& prediction of long term deterioration. Construction and Building Materials, Corrosion and Treatment of Reinforced Concrete 11, 249-254. https://doi.org/10.1016/S0950-0618(97)00044-5 